\title{
Treatment of municipal solid waste landfill leachate by use of combined biological, physical and photochemical processes
}

\author{
V.J. Inglezakis ${ }^{1}$, A. Amzebek, B. Kuspangaliyeva, Y. Sabrassov, G. Balbayeva, A. Yerkinova, and \\ S.G. Poulopoulos
}

Department of Chemical Engineering, Environmental Science \& Technology Group (ESTg), School of Engineering, Nazarbayev University, Astana, Kazakhstan.

Emails: vasileios.inglezakis@nu.edu.kz, azamat.amzebek@nu.edu.kz, botagoz.kuspangaliyeva@,nu.edu.kz,ysarbassov@nu.edu.kz,gbalbayeva@nu.edu.kz, ayerkinova@nu.edu.kz, stavros.poulopoulos@nu.edu.kz

\begin{abstract}
The purpose of this work was to study the treatment of a leachate coming from the municipal solid waste landfill of Astana (Kazakhstan). Physical (striping and adsorption), biological and photochemical processes were applied separately or in combination, and the treatment efficiency was attended in terms of carbon and nitrogen removal. The leachate carbon was by $45-60 \%$ inorganic while nitrogen was almost $100 \%$ inorganic in the form of ammonia. The results showed that inorganic carbon and ammonia can be almost entirely removed by air stripping at $\mathrm{pH}=7$ and $\mathrm{pH}=12$, respectively. The removal of organic carbon by stripping alone was lower than $4 \%$ but combined to adsorption reached $20 \%$, and to biological treatment $30 \%$. The removal of organic carbon by photochemical oxidation alone was $43 \%$. The combination of stripping, adsorption and biological treatment resulted in $37 \%$ organic carbon and with the addition of photochemical oxidation step the removal was increased to 59\%. In overall, TC removal reached $85 \%$ and $\mathrm{TN}$ removal almost $100 \%$. The results showed that the decomposition of landfill leachate carbon is a challenging task requiring a combination of processes. On the
\end{abstract}

\footnotetext{
${ }^{1}$ To whom correspondence should be addressed. Email: vasileios.inglezakis@nu.edu.kz
} 
contrary, as almost all nitrogen is inorganic, air stripping at elevated $\mathrm{pH}$ alone can sufficiently eliminate it.

Keywords: landfill leachate, activated sludge, leachate treatment, photo-Fenton.

\section{Introduction}

Despite the development of various solid waste management methods, sanitary landfilling remains the most widely used option for the disposal of municipal solid waste (MSW) [1]. Kazakhstan is not an exception including Astana, which is its capital city. At present, roughly 97\% of the generated MSW in Astana is disposed at its MSW landfill [2]. The current MSW cell of Astana has been used since 2006 and has already exceeded its capacity. By the end of 2016, this cell had received over 4 million tons of MSW while its projected capacity was 3.2 million tons. An identical new cell is being built and it is anticipated to start accepting MSW from July of 2017, while the current cell is under re-cultivation process (2017).

These MSW disposal trends can be compared with those in East-European countries; for example, in Poland and Russian Federation, 90\% and 95\% of MSW are being landfilled, respectively [3, 4]. The highest generation rate of waste per capita in EU was reported for Denmark with a waste production rate of $799 \mathrm{~kg} /$ capita and the lowest in Poland with 286 $\mathrm{kg} /$ capita (2015). The corresponding figure for Astana regarding MSW generation was roughly $526 \mathrm{~kg} /$ capita in 2015, while this value was only $343 \mathrm{~kg} /$ capita in 2004. This growth of MSW rate could be explained by the increase of population and the rapid economic development of the city; the population of Astana city has increased from 327,000 in 1998 to 880,000 in 2016. As a result, the amount of residential buildings was increased from 139 million $\mathrm{m}^{2}$ to 1760 million $\mathrm{m}^{2}$ during the same period. It is evident that the increase in population, in residential and commercial buildings, and the growth of economic activities are accompanied by increased volumes of solid waste. The composition of MSW in Astana is presented in Table 1 [5]. 
MSW landfills generate biogas and leachate as by-products. The production of biogas and leachate occurs due to the biodegradation of the organic fraction in the waste. The compacted waste layers lead to anaerobic processes in young landfills followed by anaerobic processes in older landfills (Figure 1).

Table 1. Composition of MSW in Astana city [5].

\begin{tabular}{lc}
\hline MSW & $\begin{array}{c}\text { Percentage } \\
(\%)\end{array}$ \\
\hline Organic & 28 \\
Inert & 12.4 \\
Plastic & 18.5 \\
Paper & 13 \\
Metal & 0.9 \\
Textile and leather & 9.8 \\
Landscaping & 1.5 \\
Construction & 1.4 \\
Glass & 14.5 \\
\hline
\end{tabular}

Landfill leachate from municipal solid waste is a serious growing concern for both environmental and human health in urban areas $[1,6]$. Landfill leachate is generally a dark colored liquid and contains several groups of pollutants such as organics (both biodegradable and refractory), nutrients, inorganic salts, heavy metals, high levels of total ammonium nitrogen and other toxic pollutants $[1,7,8]$. It is a wastewater with diverse composition, which exhibits a wide variation depending on the age, site hydrology, moisture and oxygen availability, and the degree of solid waste stabilization, as shown in Figure $1[4,9]$. 


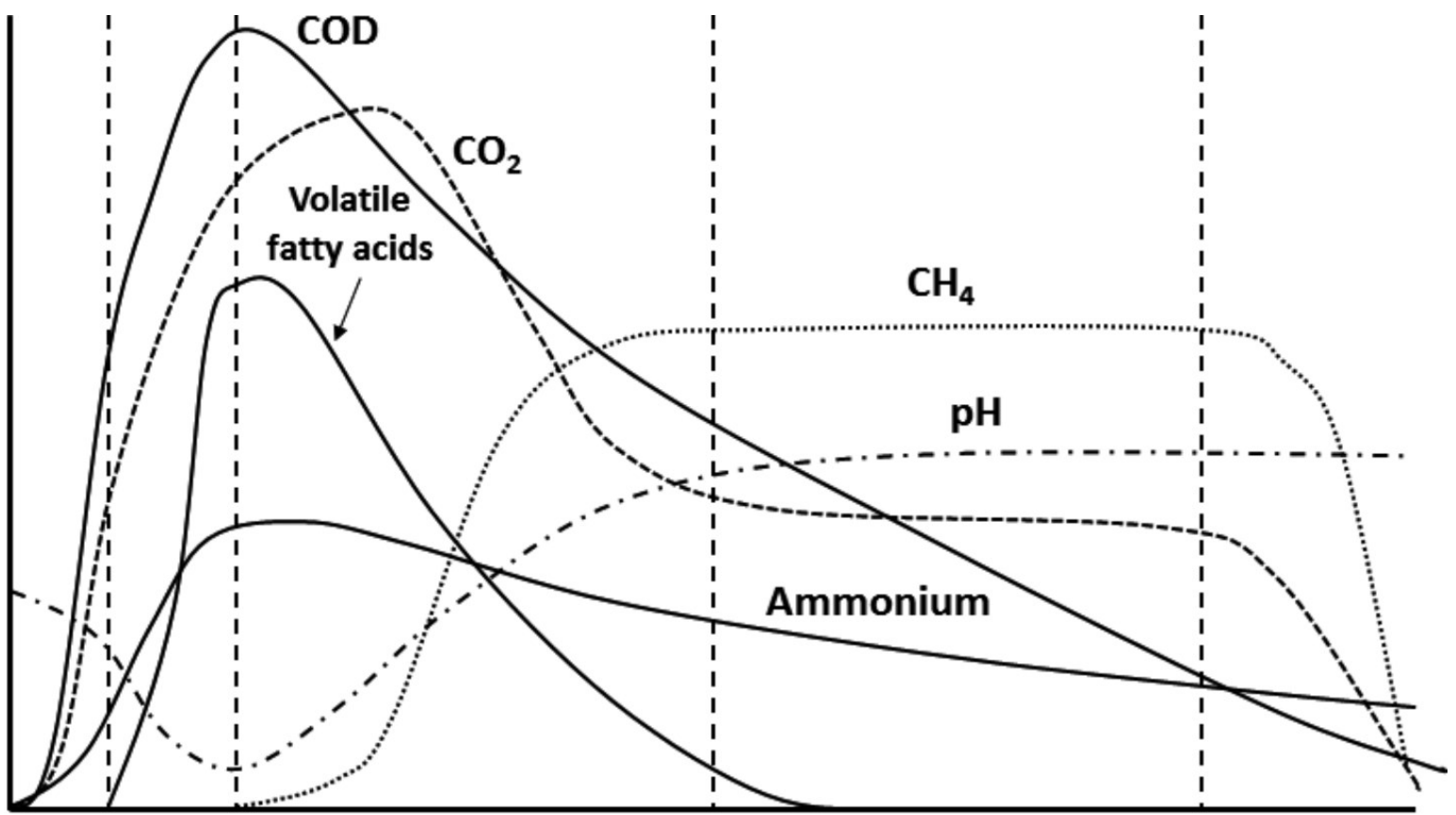

Phase 12

3

4

Figure 1. Scheme of biological treatment of leachate. 1 = aerobic phase; 2 = anaerobic acidogenic phase; 3 = unstable methanogenic phase; $4=$ stable methanogenic phase. "Reprinted from Bove et al. [9] with permission from John Wiley and Sons".

Thus, the composition of a leachate depends largely on its age. Young leachates are characterized by higher ratios of $\mathrm{BOD} / \mathrm{COD}$ and higher amounts of volatile fatty acids, while an old leachate is expected to contain high amounts of total ammonium nitrogen and low ratios of BOD/COD [8] (Table 2). Astana landfill has been used for more than 10 years and thus, the leachate collected can be considered as old, and it is expected to contain highly stabilized organic compounds as well as high concentrations of ammonia.

Table 2. Composition of leachates as a function of landfill age $[9,10]$

\begin{tabular}{|l|l|l|l|}
\hline Parameter & Young & Medium & Old \\
\hline Age (year) & $<1$ & $1-5$ & $>5$ \\
\hline $\mathrm{pH}$ & $7.2 \pm 1.0$ & $7.7 \pm 0.7$ & $8.2 \pm 0.3$ \\
\hline $\mathrm{COD}(\mathrm{mg} / \mathrm{L})$ & $24805 \pm 22982$ & $5239 \pm 2618$ & $2652 \pm 1786$ \\
\hline $\mathrm{BOD}_{5} / \mathrm{COD}$ & $0.46 \pm 0.21$ & $0.23 \pm 0.09$ & $0.121 \pm 0.07$ \\
\hline TOC/COD & $<0.3$ & $0.3-0.5$ & $>0.5$ \\
\hline
\end{tabular}




\begin{tabular}{|l|l|l|l|}
\hline $\mathrm{TN}(\mathrm{mg} / \mathrm{L})$ & $1665 \pm 1612$ & $1421 \pm 416$ & $1939 \pm 1715$ \\
\hline $\mathrm{NH}_{4}-\mathrm{N}(\mathrm{mg} / \mathrm{L})$ & $2162 \pm 1385$ & $1070 \pm 285$ & $1616 \pm 1557$ \\
\hline
\end{tabular}

Typical compositions of leachates around the world are shown in Table 3 [11-17]. Heavy metals' concentrations could also vary significantly depending on the factors noted above. Typical ranges of heavy metal concentrations found in landfill leachates are shown in Table 4 [7, 18-20]. Approximately $0.02 \%$ of the total heavy metals in a landfill are leached out in 30 years [7, 21, 22]. Apart from biochemical processes in landfills and the inherent water content of the waste, leachate is also generated by rainwater percolating through the waste layers $[4,6,15]$. In the case of Astana landfill, the precipitation and melting of snow accumulated during the winter period could also be an additional contributor to the leachate production rate. The production of leachate is continued through its operating life and also for several hundred years after recultivation of the cell [23]. The recirculation of leachate back to the landfill is a widely practiced treatment method due to its low cost [24]. The study of Rodriguez et al. [25] in an anaerobic pilot-plant reactor has showed a reduction trend for the COD with leachate recirculation. It has been reported that the recirculation of leachate reduces the time required for the stabilization [22]. It has to be noted that such a practice is rarely applied in the Astana's landfill. 
Table 3. Composition and properties of landfill leachate

\begin{tabular}{|c|c|c|c|c|c|c|c|c|c|c|c|c|c|c|}
\hline Authors $\rightarrow$ & $\begin{array}{l}\text { Kjeldsen } \\
\text { et al. [7] }\end{array}$ & $\begin{array}{c}\text { Speer } \\
\text { et al. }[14]\end{array}$ & $\begin{array}{l}\text { Modin et al. } \\
\quad[16]\end{array}$ & $\mathrm{Am}$ & iral et al. & & $\begin{array}{c}\text { Trabelsi } \\
\text { et al. } \\
{[17]}\end{array}$ & $\begin{array}{c}\text { Yaman } \\
\text { et al. }[15]\end{array}$ & $\begin{array}{c}\text { Robinson } \\
\text { [11] }\end{array}$ & $\begin{array}{l}\text { Mishra } \\
\text { et al. } \\
\text { [27] }\end{array}$ & $\begin{array}{c}\text { El- } \\
\text { Gohary } \\
\text { et al. }[28]\end{array}$ & $\begin{array}{c}\text { Dominguez } \\
\text { et al. }[29]\end{array}$ & $\begin{array}{l}\text { Alver } \\
\text { et al. } \\
{[30]}\end{array}$ & $\begin{array}{c}\text { Ramires- } \\
\text { Sosa } \\
\text { et al. } \\
{[13]}\end{array}$ \\
\hline \multirow{2}{*}{$\begin{array}{l}\text { Location } \rightarrow \\
\text { Parameters } \\
\quad(\mathrm{mg} / \mathrm{L}) \downarrow\end{array}$} & \multirow{2}{*}{ Ref. $^{2}$} & \multirow{2}{*}{$\begin{array}{c}\text { North Bay, } \\
\text { Ontario, } \\
\text { Canada }\end{array}$} & \multirow{2}{*}{ Sweden } & \multicolumn{3}{|c|}{ Brazil } & \multirow{2}{*}{ Japan } & \multirow{2}{*}{$\begin{array}{c}\text { Istanbul, } \\
\text { Turkey }\end{array}$} & \multirow{2}{*}{ UK } & \multirow{2}{*}{$\begin{array}{l}\text { Mumbai } \\
\text { India }\end{array}$} & \multirow{2}{*}{$\begin{array}{l}\text { Giza } \\
\text { Egypt }\end{array}$} & \multirow{2}{*}{$\begin{array}{l}\text { Leon } \\
\text { Spain }\end{array}$} & \multirow{2}{*}{$\begin{array}{c}\text { Aksaray } \\
\text { Turkey }\end{array}$} & \multirow{2}{*}{$\begin{array}{l}\text { Merida } \\
\text { Mexico }\end{array}$} \\
\hline & & & & $\begin{array}{c}20 \\
\text { y.o. }\end{array}$ & $\begin{array}{r}10 \\
\text { y.o. }\end{array}$ & $\begin{array}{c}5 \\
\text { y.o. }\end{array}$ & & & & & & & & \\
\hline $\mathrm{pH}$ & $4.5-9$ & $\begin{array}{c}7.1 \\
( \pm 0.2)\end{array}$ & 7.6 & $\begin{array}{c}7.8 \\
( \pm 0.3)\end{array}$ & $\begin{array}{c}7.8 \\
( \pm 0.1)\end{array}$ & $\begin{array}{c}7.5 \\
( \pm 0.8)\end{array}$ & 7.2 & $5.5-8.5$ & 8.41 & 7.77 & 8.4 & 8.00 & 7.4 & 8.3 \\
\hline $\begin{array}{l}\text { Alkalinity } \\
(\mathrm{mg} \mathrm{C} / \mathrm{L})\end{array}$ & & $\begin{array}{c}4242 \\
( \pm 280)\end{array}$ & $300^{3}$ & $\begin{array}{c}2797 \\
( \pm 559)\end{array}$ & $\begin{array}{c}6092 \\
( \pm 495)\end{array}$ & $\begin{array}{c}5570 \\
( \pm 325)\end{array}$ & & $8000-13000$ & 1820 & & & & 1165 & \\
\hline $\begin{array}{l}\text { Conductivity } \\
(\mu \mathrm{S} / \mathrm{cm})\end{array}$ & $\begin{array}{l}2500- \\
35000\end{array}$ & & & & & & & $30000-40000$ & & 22.99 & & & & \\
\hline TS & $\begin{array}{l}2000- \\
60000\end{array}$ & & & & & & & & & & & & & $\begin{array}{l}19128 \\
( \pm 473)\end{array}$ \\
\hline TSS & & & & $\begin{array}{c}321 \\
( \pm 222)\end{array}$ & $\begin{array}{c}58 \\
( \pm 54)\end{array}$ & $\begin{array}{c}37 \\
( \pm 10)\end{array}$ & & $300-1500$ & & 1356 & 938.5 & 7258 & 582 & $\begin{array}{c}357 \\
( \pm 33)\end{array}$ \\
\hline Total COD & $\begin{array}{c}140- \\
152000\end{array}$ & $995( \pm 290)$ & 560 & $\begin{array}{c}1352 \\
( \pm 561)\end{array}$ & $\begin{array}{c}2572 \\
( \pm 528)\end{array}$ & $\begin{array}{c}2783 \\
( \pm 623)\end{array}$ & 181 & $11640-19475$ & 1900 & 6444 & 15225 & 9612 & 26183 & $\begin{array}{l}10434 \\
( \pm 441)\end{array}$ \\
\hline Soluble COD & & & & & & & & & & & 13250 & & & $\begin{array}{l}10217 \\
( \pm 400)\end{array}$ \\
\hline Total $\mathrm{BOD}_{5}$ & $20-57000$ & & 12 & $\begin{array}{c}76 \\
( \pm 41)\end{array}$ & $\begin{array}{c}168 \\
( \pm 43)\end{array}$ & $\begin{array}{c}150 \\
( \pm 60)\end{array}$ & 228 & $3000-13000$ & 7.6 & 3391 & 5710 & & 17750 & $\begin{array}{c}942 \\
( \pm 236)\end{array}$ \\
\hline Soluble TC & & & & & & & & & & & & & & $\begin{array}{c}4975 \\
( \pm 360)\end{array}$ \\
\hline Soluble TOC & $30-29000$ & & 150 & & & & 194 & & 776 & & & 1358 & & $\begin{array}{c}2808 \\
( \pm 197)\end{array}$ \\
\hline $\mathrm{TN}$ & $14-2500^{4}$ & $\begin{array}{c}535 \\
( \pm 214)\end{array}$ & 190 & $\begin{array}{c}532 \\
( \pm 187)\end{array}$ & $\begin{array}{c}1307 \\
( \pm 312)\end{array}$ & $\begin{array}{c}1112 \\
( \pm 417)\end{array}$ & 427 & $3482-3548$ & & & & 517 & 1318 & \\
\hline Nitrate & & $<$ D.L. ${ }^{5}$ & & & & & 3.33 & & 1800 & & 0.05 & 21 & & \\
\hline Ammonium-N & $50-2200$ & & & & & & 351 & $2599-2713$ & & & & & & \\
\hline
\end{tabular}

\footnotetext{
2 The ranges are based on Andreottola and Cannas [31], Chu et al. [32], Robinson [33], Ehrig [34], Ehrig [35], Ehrig [36], Garland and Mosher [37], Johansen and Carlson [38], Karstensen [39], Krug and Ham [40], Lu et al. [41], NaturvArdsverket [42], Owen and Manning [43], and Robinson and Mafis [44].

${ }^{3}$ Alkalinity as $\mathrm{CaCO}_{3}$

4 Organic nitrogen

$5<$ D.L. denotes concentration below the detection limit $(3 \mathrm{mg} / \mathrm{L})$
} 


\begin{tabular}{|c|c|c|c|c|c|c|c|c|c|c|c|c|c|c|}
\hline Ammonia-N & 740 & $\begin{array}{c}515 \\
( \pm 29)\end{array}$ & & $\begin{array}{c}451 \\
( \pm 173)\end{array}$ & $\begin{array}{c}1240 \\
( \pm 570)\end{array}$ & $\begin{array}{c}793 \\
( \pm 374)\end{array}$ & & & & & 5208 & 447 & & \\
\hline TP & $0.1-23$ & $\begin{array}{c}3.0 \\
( \pm 1.7)\end{array}$ & 0.59 & $\begin{array}{c}7.0 \\
( \pm 1.5)\end{array}$ & $\begin{array}{c}12 \\
( \pm 0.7)\end{array}$ & $\begin{array}{c}11 \\
( \pm 3.6)\end{array}$ & & $14.8-25.1$ & 7.83 & 82.36 & 48.2 & 34 & 31 & \\
\hline Chlorine & $150-4500$ & & 780 & $\begin{array}{c}1708 \\
( \pm 333)\end{array}$ & $\begin{array}{c}2960 \\
( \pm 124)\end{array}$ & $\begin{array}{c}2973 \\
( \pm 161)\end{array}$ & 744 & & 3490 & 3584 & & 2353 & 1805 & 2200 \\
\hline Sulfate & $8-7750$ & & & & & & & $5-500$ & 165 & 854 & & 39 & 379 & \\
\hline
\end{tabular}


Table 4. Range of heavy metals concentrations in landfill leachates

\begin{tabular}{|c|c|c|c|c|c|c|c|c|c|c|}
\hline \multirow[t]{2}{*}{$\begin{array}{l}\text { Authors/ } \\
\text { Locations } \\
\rightarrow\end{array}$} & $\begin{array}{l}\text { Xie et al. } \\
\text { [18] }\end{array}$ & $\begin{array}{c}\text { Speer et al. } \\
{[14]}\end{array}$ & $\begin{array}{l}\text { Modin } \\
\text { et al. } \\
{[16]}\end{array}$ & \multicolumn{3}{|c|}{$\begin{array}{c}\text { Naveen et al. } \\
\text { [12] }\end{array}$} & $\begin{array}{c}\text { Robinso } \\
\mathrm{n} \\
{[11]}\end{array}$ & $\begin{array}{c}\text { Baun and } \\
\text { Christense } \\
\text { n [20] }\end{array}$ & $\begin{array}{c}\text { Kjeldse } \\
\text { n et al. } \\
{[7]}\end{array}$ & $\begin{array}{c}\text { Barlaz et } \\
\text { al. [19] }\end{array}$ \\
\hline & $\begin{array}{c}\text { Queensland } \\
\text { Australia }\end{array}$ & $\begin{array}{c}\text { North Bay, } \\
\text { Ontario, } \\
\text { Canada }\end{array}$ & Sweden & \multicolumn{3}{|c|}{ Bangalore, India } & $\begin{array}{c}\text { England, } \\
\text { United } \\
\text { Kingdo } \\
\text { m }\end{array}$ & Ref. $^{6}$ & Ref. $^{7}$ & $\begin{array}{c}\text { North } \\
\text { America }\end{array}$ \\
\hline $\begin{array}{l}\text { Metals } \\
\text { (mg/L) } \downarrow\end{array}$ & $\begin{array}{l}\text { Landfill } \\
\text { bioreactor } \\
\text { leachate }\end{array}$ & $\begin{array}{c}\text { Raw } \\
\text { leachate }\end{array}$ & $\begin{array}{c}\text { Untreate } \\
\mathrm{d} \\
\text { leachate }\end{array}$ & $\mathrm{L}^{8}{ }^{8}$ & $\mathrm{P} 4^{9}$ & $\mathrm{G} 5^{10}$ & $\begin{array}{c}\text { Not } \\
\text { filtered }\end{array}$ & $\begin{array}{l}\text { Landfill } \\
\text { leachate }\end{array}$ & $\begin{array}{l}\text { Landfill } \\
\text { leachate }\end{array}$ & $\begin{array}{c}\text { Bioreacto } \\
\text { r landfill } \\
\text { lechate }\end{array}$ \\
\hline Iron & $\begin{array}{c}8.64 \\
( \pm 0.25)\end{array}$ & $\begin{array}{c}19.0( \pm 14.6 \\
)\end{array}$ & 2.3 & 11.16 & 0.16 & 0.62 & 4.06 & $0.08-2100$ & $3-5500$ & \\
\hline Zinc & $\begin{array}{c}1.87 \\
( \pm 0.06)\end{array}$ & $0.5( \pm 0.3)$ & 0.084 & 3 & 1 & 0.4 & 220 & $0.01-155$ & $\begin{array}{l}0.03- \\
1000\end{array}$ & $0-112$ \\
\hline Copper & $\begin{array}{c}0.28 \\
( \pm 0.01)\end{array}$ & & 0.034 & 0.151 & BDL & BDL & 4.76 & $0.0005-1.4$ & $\begin{array}{c}0.005- \\
10\end{array}$ & $\begin{array}{c}0.003- \\
0.49\end{array}$ \\
\hline Lead & $\begin{array}{c}0.41 \\
( \pm 0.06)\end{array}$ & & 0.00082 & 0.3 & BDL & BDL & $<0.5$ & $0.0005-1.5$ & $0.001-5$ & $0-0.3$ \\
\hline Nickel & $\begin{array}{c}0.78 \\
( \pm 0.02)\end{array}$ & & 0.061 & 1.339 & BDL & BDL & 406 & $0.001-3.2$ & $\begin{array}{c}0.015- \\
13\end{array}$ & \\
\hline Arsenic & $\begin{array}{c}0.11 \\
( \pm 0.03)\end{array}$ & & 0.022 & $\underset{11}{\mathrm{BDL}}$ & & & 200 & $0.0005-1.6$ & $0.01-1$ & $\begin{array}{c}0.005- \\
0.155\end{array}$ \\
\hline Silver & & & & 0.035 & $\begin{array}{c}0.02 \\
6\end{array}$ & $\begin{array}{c}0.05 \\
1\end{array}$ & & & & \\
\hline Cadmium & $\begin{array}{c}0.00 \\
( \pm 0.00)\end{array}$ & & 0.000027 & 0.035 & BDL & BDL & $<0.5$ & $\begin{array}{c}0.00002- \\
0.13\end{array}$ & $\begin{array}{c}0.0001- \\
0.4\end{array}$ & $0-0.419$ \\
\hline Cobalt & $\begin{array}{c}0.14 \\
( \pm 0.02)\end{array}$ & & 0.012 & & & & & $0.001-0.95$ & $\begin{array}{c}0.005- \\
1.5\end{array}$ & \\
\hline $\begin{array}{l}\text { Chromiu } \\
\text { m }\end{array}$ & $\begin{array}{c}0.13 \\
( \pm 0.02)\end{array}$ & & 0.039 & 0.021 & BDL & BDL & 639 & $0.0005-1.6$ & $0.02-1.5$ & $0-1.98$ \\
\hline Strontium & & $1.7( \pm 0.2)$ & 5.3 & & & & & & & \\
\hline
\end{tabular}

It is evident thus that there is a variety of leachates with diverse compositions, which imposes the need to apply different treatment methods depending on the exact case [49]. For instance, it is easier to process young leachates in comparison with old ones. For a number of environmental and public health reasons, it is essential to investigate suitable landfill leachate treatment methods [50]. Wiszniowski et al. [51] categorized leachate treatment methods into two basic groups: a) chemical and physical treatment, b) biological treatment.

Physical-chemical methods are used to remove refractory and non-biodegradable substances, and also to improve biologically pre-treated stabilized leachates [4]. They are often applied as a pre-

\footnotetext{
${ }^{6}$ From Kjeldsen and Christophersen [45], Krug and Ham [46], Clement and Thomas [47], Jorgensen and Kjeldsen [48], Robinson [33], Chu et al. [32], Ehrig [36], Ehrig [35], and Johansen and Carlson [38]

${ }^{7}$ The ranges are based on Andreottola and Cannas [31], Chu et al. [32], Robinson [33], Ehrig [34], Ehrig [35], Ehrig [36], Garland and Mosher [37], Johansen and Carlson [38], Karstensen [39], Krug and Ham [40], Lu et al. [41], NaturvArdsverket [42], Owen and Manning [43], and Robinson and Mafis [44].

${ }^{8}$ L1-landfill side (close to cell)

${ }^{9}$ P4-pond

${ }^{10}$ G5-open well

11 BDL-Below detection limit
} 
treatment step for fresh leachates prior to biological treatment, or as a post-treatment and purification step when biological oxidation is restricted due to the presence of bio-refractory compounds. The main techniques of physical treatment are air-stripping, membrane filtration, adsorption and sedimentation [52, 53], while chemical precipitation, coagulation-flocculation and chemical-electrochemical oxidation are the most common chemical treatment options [54, 55]. An alternative and cheap option, especially applicable in poor regions, is the treatment in constructed wetlands and variations of onsite anaerobic-aerobic lagoons. This method is essentially biological treatment and has been proven efficient under certain conditions and leachate characteristics [4].

Air stripping is a process of passing a large volume of air through the leachate to enhance mass transfer of undesirable substances from the liquid to gas phase [56]. The efficiency of air stripping can be significantly improved by increasing values of $\mathrm{pH}$ and temperature. Typically, air stripping is held at a $\mathrm{pH} 10-11$ and in the temperature range of $60-70^{\circ} \mathrm{C}$ [4]. Air stripping generates gas emissions containing mainly carbon dioxide, ammonia and smaller amounts of VOCs that may contribute to air pollution or greenhouse effect if released without appropriate treatment. Adsorption is used to remove refractory organic compounds and ammonium nitrogen. The main adsorbent agents used are powdered or granulated activated carbons (AC) and zeolites. Their frequent application is owed to their highly porous structure and large surface areas, thermal stability, resistance to acids and bases, and high removal efficiency of organic and inorganic pollutants from leachates [57-59]. Activated carbons are usually applied as a step in the physicochemical treatment train or as a tertiary treatment to remove non-biodegradable substances. They may also adsorb non-biodegradable products (SMP) of microbial origin. Advanced Oxidation Processes (AOPs) have been also used to eliminate organic pollutants in landfill leachates [60]. For example, photocatalytic treatment under UV-irradiated $\mathrm{TiO}_{2}$ suspension can oxidize natural products, such as glucose, ethanol, cellulose and others, and toxic chemicals like chlorinated hydrocarbons, into $\mathrm{CO}_{2}, \mathrm{H}_{2}$ and $\mathrm{HCl}$ end-products. Photo-assisted Fenton reaction ( $\mathrm{Fe}(\mathrm{II})+\mathrm{H}_{2} \mathrm{O}_{2}$ ) with UV light has been also applied to decrease up to $70 \%$ the COD of a landfill leachate [61]. 
Biological treatment (aerobic or/and anaerobic) is the most commonly used way to reduce organic substances in landfill leachates [49]. However, its activity decreases with increasing of landfill's age due to the fact that biodegradation of organic matter reduces over time and leachate becomes stabilized [8]. Aerobic treatment used alone in a sequencing batch reactor (SBR) resulted in a $99 \% \mathrm{~N}^{-N_{4}}$ removal in about 30 days [62]. The anaerobic biological treatment was found to be more effective than the aerobic in terms of COD removal [63]. Moreover, anaerobic and aerobic steps can be combined in series for more efficient process; for instance, Kettunen et al. [64] achieved a COD removal of $80-90 \%$ and ammonium removal of $80 \%$.

In most cases, however, a combination of methods is applied for the effective treatment of landfill leachates. For example, adsorption by means of activated carbon has been used in combination with bio-processes in a number of studies in order to enhance the removal of refractory organic compounds and nitrification [59, 65]. Park et al. [66] applied a combination of the biological method, adsorption, precipitation, flocculation and reverse osmosis, to achieve removal of organic compounds in a landfill leachate about 98\%. Marttinen et al. [55] investigated the efficiency of ozonation, nanofiltration and air-stripping in removing COD, toxic compounds and ammonium as pretreatment stages in order to prevent the inhibition effects on biomass, while Steensen [67] applied chemical oxidation in the treatment of a leachate, which was pretreated by biological method, and non-biodegradable organic matter was reduced by ozone/fixed bed catalyst and $\mathrm{UV} / \mathrm{H}_{2} \mathrm{O}_{2}$ techniques.

In the present work, the effectiveness of air stripping at different $\mathrm{pH}$, adsorption by means of activated carbon (AC) and natural zeolite (NZ), biological treatment by use of recycled municipal activated sludge (RAS) and photo-oxidation process using $\mathrm{UV} / \mathrm{H}_{2} \mathrm{O}_{2} / \mathrm{Fe}(\mathrm{III})$, for the treatment of landfill leachate was studied. The effect of processes' parameters was investigated and treatment effectiveness was monitored via $\mathrm{pH}$, conductivity, Total Organic Carbon (TOC), Inorganic Carbon (IC), Total Nitrogen (TN) and dissolved ions of $\mathrm{NH}_{4}^{+}, \mathrm{NO}_{2}^{-}$and $\mathrm{NO}_{3}^{-}$ measurements.

\section{Materials and Methods}




\subsection{Experimental setup of the biological process}

The experimental setup of the biological process consisted of $1 \mathrm{~L}$ borosilicate beakers with a total operating volume of $0.6 \mathrm{~L}$. Continuous stirring was applied using magnetic stirrer, and samples were aerated using air pumps and diffusers. Throughout the study, the amount of the leachate treated was $250 \mathrm{~mL}$, which was subsequently diluted to final reactor volume of $600 \mathrm{~mL}$ with tap water or tap water and activated sludge (Table 5). The average TSS (Total Suspended Solids) of the bioreactors was $2.38 \pm 0.03 \mathrm{~g} / \mathrm{L}$ and the HRT (Hydraulic Retention Time) 1.5 days. The amount of substrate that was fed to the amount of biomass in the system (F/M ratio) was 1.16$1.25 \mathrm{kgTOC} / \mathrm{kg}$ TSS* d.

\subsection{Landfill leachate and activated sludge samples}

The leachate was sampled from the Municipal Solid Waste landfill of Astana city between September and October 2017. Samples were collected from the upper side of the leachate reservoir and kept at $4^{\circ} \mathrm{C}$ in sealed plastic containers. Due to the high total solids (TS) content, the leachate was left for sufficient time for solids to settle and the supernatant solution was used for the experiments. The activated sludge used was sampled weekly from the wastewater treatment plant “Astana Su Arnasy” (Astana, Kazakhstan). After sampling, it was aerated for 24 $\mathrm{h}$ before use.

\subsection{Adsorbents}

The zeolite used was clinoptilolite of purity 50-84\% from Taldykorgan region, Kazakhstan. The particle size was mixed; from dust up to $5 \mathrm{~mm}$. The activated carbon was of commercial grade and average particle size of $1.5 \mathrm{~mm}$. Solids were washed with pure water, dried in the oven for 24 hours at $105^{\circ} \mathrm{C}$, and stored in the desiccator until used.

\subsection{Experimental procedure for physical and biological processes}

The following sets of experiments were conducted (Table 5):

a) The effect of aeration was first studied by mixing $250 \mathrm{~mL}$ of leachate and $350 \mathrm{~mL}$ of tap water, under continuous stirring for 24 hours (Experiment 1). This set up was used as reference reactors for all experiments as well. 
b) The effect of aeration under high $\mathrm{pH}$ was studied by mixing $250 \mathrm{~mL}$ of leachate and 350 $\mathrm{mL}$ of tap water, under continuous stirring for 17 hours (Experiment 2). This type of pretreatment is important for an efficient biological treatment since ammonia is removed by air stripping [57]. To increase $\mathrm{pH}$ from 8.5 to 12 , concentrated potassium hydroxide solution was used. At the end of the pretreatment step, $\mathrm{pH}$ was reduced manually to 7 by use of hydrochloric acid before the initiation of the biological treatment.

c) The effect of solids addition was studied by adding equal amounts of activated carbon and natural zeolite in the reactor, ranging in 3-18 g/L. Aeration and agitation were constantly applied throughout the experiment. Reference reactors were used as well, containing the same liquid mixture but without the solids (Experiments 3-7).

d) Biological treatment was conducted in aerobic, anaerobic and combined aerobic/anaerobic conditions (Experiments 8-16). Specifically, $250 \mathrm{~mL}$ of leachate was mixed with $200 \mathrm{~mL}$ of activated sludge, and diluted to $600 \mathrm{~mL}$ with tap water. During aerobic treatment, the reactors were under constant mixing and aeration using air pumps, whereas anaerobic condition was accomplished by sealing the reactor with parafilm under constant stirring under aeration. The duration of the experiments was $24 \mathrm{~h}$ hours and the HRT 1.5 days. Such short experiments can be useful for preliminary assessments, as discussed for example in Aghamohammadi et al. [59] and Kargi and Pamukoglu [57]. To observe the effect of $\mathrm{pH}$ on bioreactors performance, additional experiments were conducted. A set of experiments was conducted with initial adjustment of $\mathrm{pH}$ to 7 using concentrated hydrochloric acid with no further intervention (Experiments 9-11). As pH increased with time and in order to ensure the bacterial activity of activated sludge, $\mathrm{pH}$ was manually adjusted in the range of 7-8 in the third experimental set for the first 2.5 hours (Experiments 12-13). Finally, combined anaerobic/aerobic treatment was studied (Experiments 14-16).

All experiments were run at least in duplicates along with a reference reactor. The average standard deviation between the results of the duplicate reactors was $6.7 \pm 6 \%$ for TC (29 runs, 52 reactors), $8.4 \pm 9.3 \%$ for TIC (18 runs, 36 reactors) and $15.7 \pm 13 \%$ for $\mathrm{N}-\mathrm{NH}_{4}$ (16 runs, 32 reactors). 
Samples were collected from supernatant solution after solid particles were settled, and filtered through 1.2 and, if necessary, though 0.45 microns filters, diluted with ultrapure water, and stored at $4^{\circ} \mathrm{C}$ before analysis. 
Table 5. Experimental details for physical and biological processes

\begin{tabular}{|c|c|c|c|c|c|c|c|}
\hline Run & $\begin{array}{c}\text { Tap } \\
\text { water } \\
(\mathrm{ml})\end{array}$ & $\begin{array}{c}\text { Leachate } \\
(\mathrm{ml})\end{array}$ & $\begin{array}{c}\text { Activated } \\
\text { sludge } \\
(\mathrm{ml})\end{array}$ & $\begin{array}{l}\text { Solids } \\
\text { mass } \\
(\mathrm{g} / \mathrm{L})\end{array}$ & Pretreatment & $\begin{array}{l}\text { Bioreactor mode } \\
\text { Aero: Aerobic } \\
\text { Anox: Anoxic }\end{array}$ & $\begin{array}{c}\mathrm{pH} \\
\text { A: initial adjustment } \\
\text { C: Control }\end{array}$ \\
\hline 1 & 350 & 250 & 0 & 0 & - & - & - \\
\hline 2 & 350 & 250 & 0 & 0 & - & - & $12(\mathrm{~A})$ \\
\hline 3 & 350 & 250 & 0 & 3 & - & - & - \\
\hline 4 & 350 & 250 & 0 & 9 & - & - & - \\
\hline 5 & 350 & 250 & 0 & 12 & - & - & - \\
\hline 6 & 350 & 250 & 0 & 15 & - & - & - \\
\hline 7 & 350 & 250 & 0 & 18 & - & - & - \\
\hline 8 & 150 & 250 & 200 & 0 & - & Aero & - \\
\hline 9 & 150 & 250 & 200 & 0 & - & Aero & 7 (A) \\
\hline 10 & 150 & 250 & 200 & 9 & - & Aero & $7(\mathrm{~A})$ \\
\hline 11 & 150 & 250 & 200 & 0 & - & Anox & 7 (A) \\
\hline 12 & 150 & 250 & 200 & 0 & $17 \mathrm{~h}, \mathrm{pH}=12$ & Aero & 7 (C) for $2.5 \mathrm{~h}$ \\
\hline 13 & 150 & 250 & 200 & 9 & $17 \mathrm{~h}, \mathrm{pH}=12$ & Aero & 7 (C) for $2.5 \mathrm{~h}$ \\
\hline 14 & 150 & 250 & 200 & 0 & $17 \mathrm{~h}, \mathrm{pH}=12$ & Aero(12h)+Anox(12h) & 7 (A) \\
\hline 15 & 150 & 250 & 200 & 0 & $17 \mathrm{~h}, \mathrm{pH}=12$ & $\operatorname{Anox}(12 \mathrm{~h})+\operatorname{Aero}(12 \mathrm{~h})$ & $7(\mathrm{~A})$ \\
\hline 16 & 150 & 250 & 200 & 9 & $17 \mathrm{~h}, \mathrm{pH}=12$ & Anox(12h)+Aero(12h) & $7(\mathrm{~A})$ \\
\hline
\end{tabular}

\subsection{Photochemical treatment}

Three leachate samples were used for photochemical treatment experiments: (a) raw leachate (250 $\mathrm{ml}$ leachate to $600 \mathrm{ml}$ final volume, as in the physical and biological treatment experiments,) with initial TC concentration around 2450-2700 mg/L (45\% inorganic carbon), TN

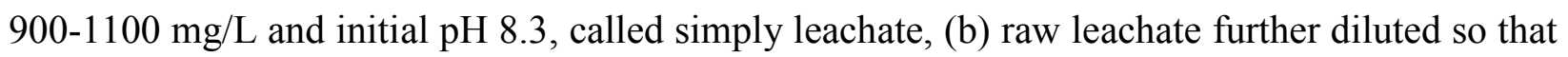
initial TC was around $540 \mathrm{mg} / \mathrm{L}$, called diluted leachate, and (c) the treated leachate from the experiment 12 (pretreatment at $\mathrm{pH} \mathrm{12,} \mathrm{pH}$ control at 7, aerated bioreactor with $9 \mathrm{~g} / \mathrm{L}$ solids) (Experiment 13, Table 5), called treated leachate.

Photochemical experiments were conducted in an annular photoreactor operated in batch recycle mode, as shown in Figure 2. Specifically, the total leachate volume to be treated was $250 \mathrm{~mL}$, whereas the active (irradiated) volume $55.8 \mathrm{~mL}$. Ultraviolet light of $254 \mathrm{~nm}$ was produced from 
an $6 \mathrm{~W}$ lamp placed inside the photoreactor. Depending on the case, $\mathrm{H}_{2} \mathrm{O}_{2}$ ranged in 2664-13320 $\mathrm{mg} / \mathrm{L}$ and $\mathrm{Fe}(\mathrm{III})$ in $0-140 \mathrm{ppm}$. A peristaltic pump with a rate of $175 \mathrm{~mL} / \mathrm{min}$ was used to continuously circulate the wastewater solution. A magnetic stirrer was used to constantly mix the part of the solution that was not irradiated by the UV-lamp. Throughout the whole duration of each experiment, $\mathrm{pH}$ was measured. Experiments lasted 120-150 minutes. The start of each experiment was considered immediately as the UV-lamp with the pump was turned on. Samples were taken periodically and sent for analysis.

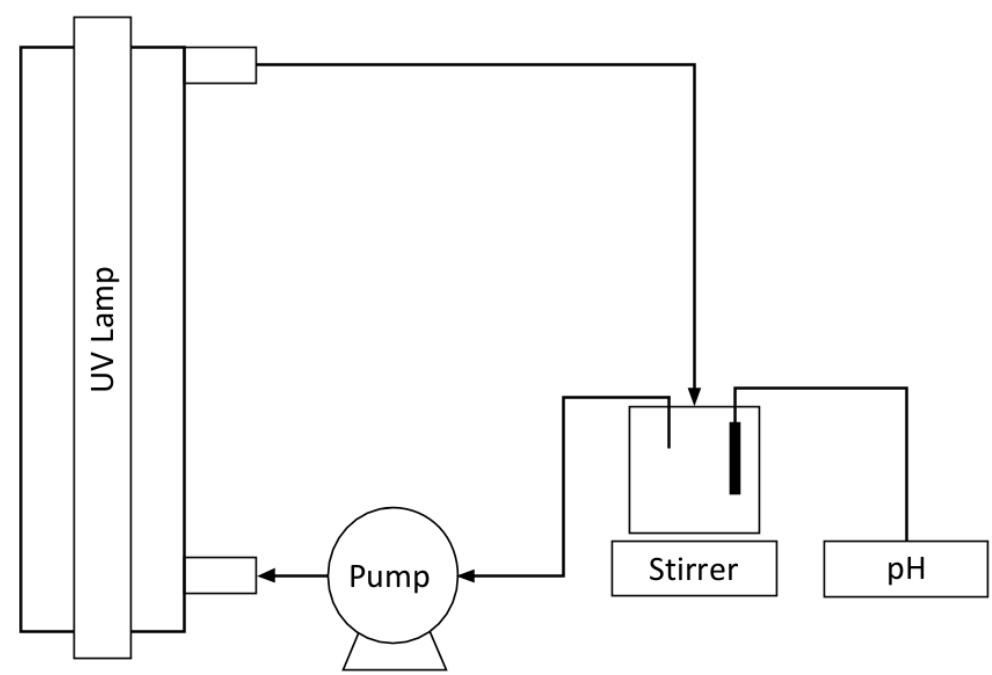

Figure 2. The experimental setup of photochemical treatment.

\subsection{Analytical methods}

Collected samples were equilibrated to room temperature and diluted with ultrapure water. Ion chromatography analysis was used for the analysis of $\mathrm{NH}_{4}{ }^{+}, \mathrm{NO}_{2}{ }^{-}$and $\mathrm{NO}_{3}$ according to the method 4110B IC with chemical Suppression of Effluent Conductivity [68] by use of Metrohm IC 930 system. Total carbon, total inorganic carbon and total nitrogen analysis was conducted using the Multi N/C 3100 analyser by Atalytik Jena AG. The pH was measured using a digital pH/ion meter (Mettler Toledo S220) and conductivity was measured with digital EC meter (Five Easy ${ }^{\mathrm{TM}}$.FE 30). Total suspended solids (TSS) of leachate and activated sludge in the reactor were measured by filtering $20 \mathrm{ml}$ of sample though a glass fiber filter paper with porosity grade of 1.2 $\mu \mathrm{m}$ under vacuum. The filters were dried for 24 hours in the oven at $105^{\circ} \mathrm{C}$ to remove all water after passing the samples through, and then they were cooled in the desiccators and weighted. 
Total solids (TSS) of leachate was measured by placing $45 \mathrm{ml}$ of sample in a beaker in an oven at $105^{\circ} \mathrm{C}$ for $24 \mathrm{~h}$. All samples were analyzed at least twice.

\section{Results and Discussion}

\subsection{Leachate composition}

The composition and properties of the leachate studied are presented in Table 6. The average amount of organic carbon contained in leachate constituted $60 \%$ of total and the remaining was inorganic carbon including carbonates and dissolved carbon dioxide. Total nitrogen analysis and $\mathrm{N}-\mathrm{NH}_{4}{ }^{+}$showed that almost all nitrogen contained was in ammonium form with only traces of nitrogenous organic compounds present. The results obtained showed that the leachate under study had high concentration ammonium and $\mathrm{pH}$ of 8.5.

Table 6. Leachate composition of Astana MSW Landfill

\begin{tabular}{ll}
\hline Parameters & Range \\
\hline $\mathrm{pH}$ & $8.1-8.5$ \\
Conductivity $(\mathrm{mS} / \mathrm{cm})$ & 24.6 \\
$\mathrm{TSS}(\mathrm{g} / \mathrm{L})$ & $0.17 \pm 0.02$ \\
$\mathrm{TS}(\mathrm{g} / \mathrm{L})$ & $13.5 \pm 1.7$ \\
$\mathrm{TC}(\mathrm{mg} / \mathrm{L})$ & $4556-5276$ \\
$\mathrm{TIC}(\mathrm{mg} / \mathrm{L})$ & $1799-1918$ \\
$\mathrm{TOC}(\mathrm{mg} / \mathrm{L})$ & $2758-2998$ \\
$\mathrm{TN}(\mathrm{mg} / \mathrm{L})$ & $2038-2278$ \\
$\mathrm{~N}^{-N H}{ }^{+}(\mathrm{mg} / \mathrm{L})$ & $1918-2398$ \\
Chloride $(\mathrm{mg} / \mathrm{L})$ & $3357-3597$ \\
Sodium $(\mathrm{mg} / \mathrm{L})$ & $2638-3118$ \\
Potassium $(\mathrm{mg} / \mathrm{L})$ & $1439-1799$ \\
Magnesium $(\mathrm{mg} / \mathrm{L})$ & $84-114$ \\
Calcium $(\mathrm{mg} / \mathrm{L})$ & $48-60$ \\
Iron $(\mathrm{mg} / \mathrm{L})$ & $23.87-35.7$ \\
Nitrate $(\mathrm{mg} / \mathrm{L})$ & $0-36$ \\
Zinc $(\mathrm{mg} / \mathrm{L})$ & $0.275-1.194$ \\
Chromium $(\mathrm{mg} / \mathrm{L})$ & $0.625-0.893$ \\
Manganium $(\mathrm{mg} / \mathrm{L})$ & $0.391-0.446$ \\
Lead $(\mathrm{mg} / \mathrm{L})$ & $0.172-0.184$ \\
Cadmium $(\mu \mathrm{g} / \mathrm{L})$ & $13-18$ \\
Cobalt $(\mu \mathrm{g} / \mathrm{L})$ & $96-130$ \\
Cooper $(\mu \mathrm{g} / \mathrm{L})$ & $12-16$ \\
Mercury $(\mu \mathrm{g} / \mathrm{L})$ & $0.2-2.1$ \\
\hline
\end{tabular}




\subsection{Effect of air stripping}

Figure 3 shows the results of air stripping at the initial $\mathrm{pH}$ of the leachate (Experiment 1) and pretreatment results at $\mathrm{pH} 12$ (Experiment 2). The removal observed at the end of the $24 \mathrm{~h}$ operation at $\mathrm{pH} 8.5$ was $45 \%$ for TIC and $51 \%$ for $\mathrm{TN}$, which was due to the effect of stripping of dissolved carbon dioxide and ammonium. Also, the slight removal of organic carbon (below $4 \%$ ) was due to the evaporation of Volatile Organic Compounds (VOCs). The $\mathrm{pH}$ was increased from 8-8.5 to 9.2-9.5 in all experiments. Under $\mathrm{pH} 12,94 \%$ removal of $\mathrm{NH}_{4}-\mathrm{N}$ was observed while TOC was not affected and TIC was considerably increased by $70.4 \%$.

In order to explain these observations, the carbonate and ammonium-ammonia equilibrium systems are discussed in the following paragraphs.

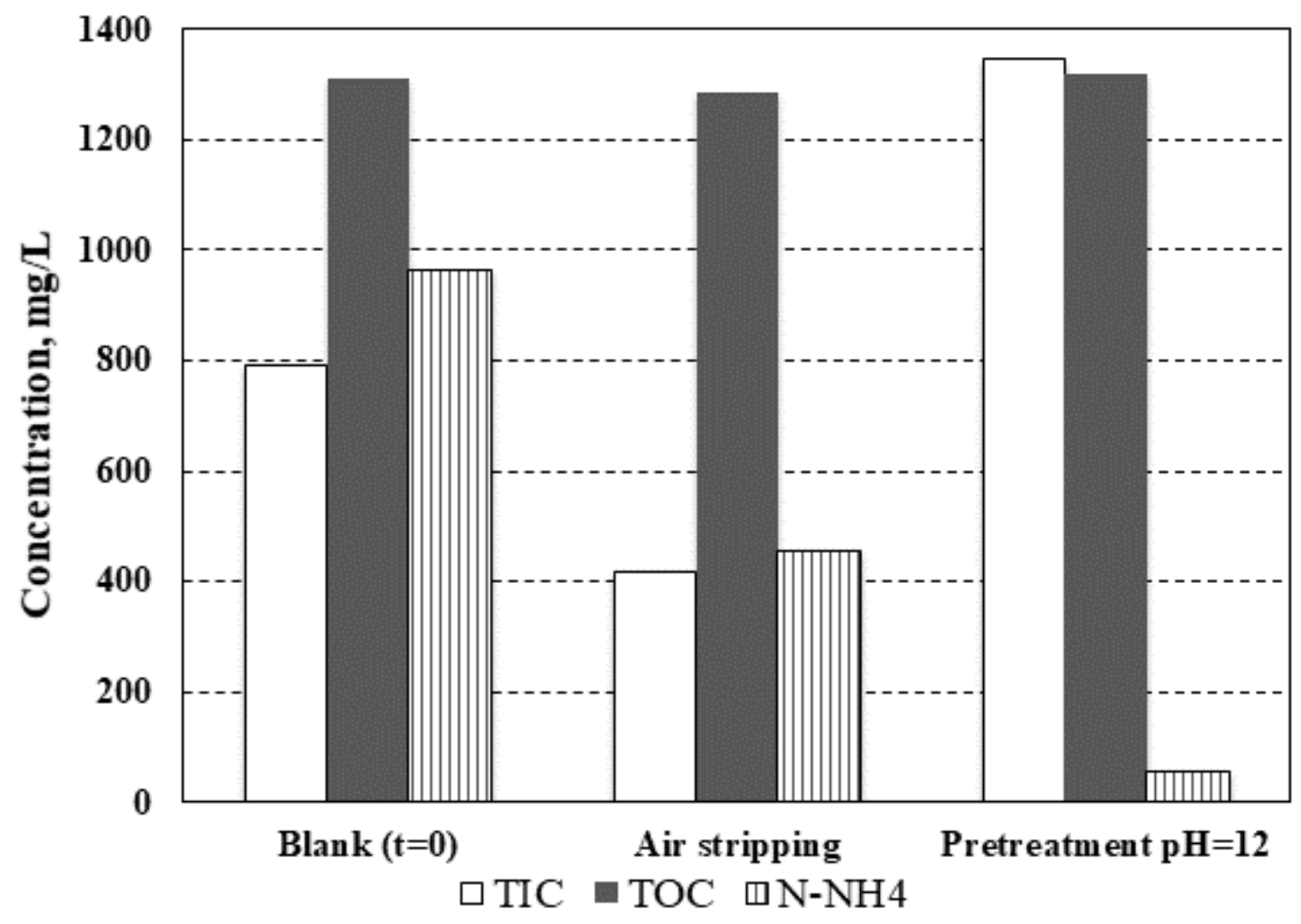

Figure 3. Effects of stripping under different $\mathrm{pH}$ values.

\subsubsection{Ammonia/Ammonium system}

The ammonia-ammonium equilibrium is: 


$$
\mathrm{NH}_{3}+\mathrm{H}_{2} \mathrm{O} \leftrightarrow \mathrm{NH}_{4}^{+}+\mathrm{OH}^{-}
$$

Ammonia is extremely soluble in water but it can be stripped under aeration. Ammonia speciation is presented in Figure 4.

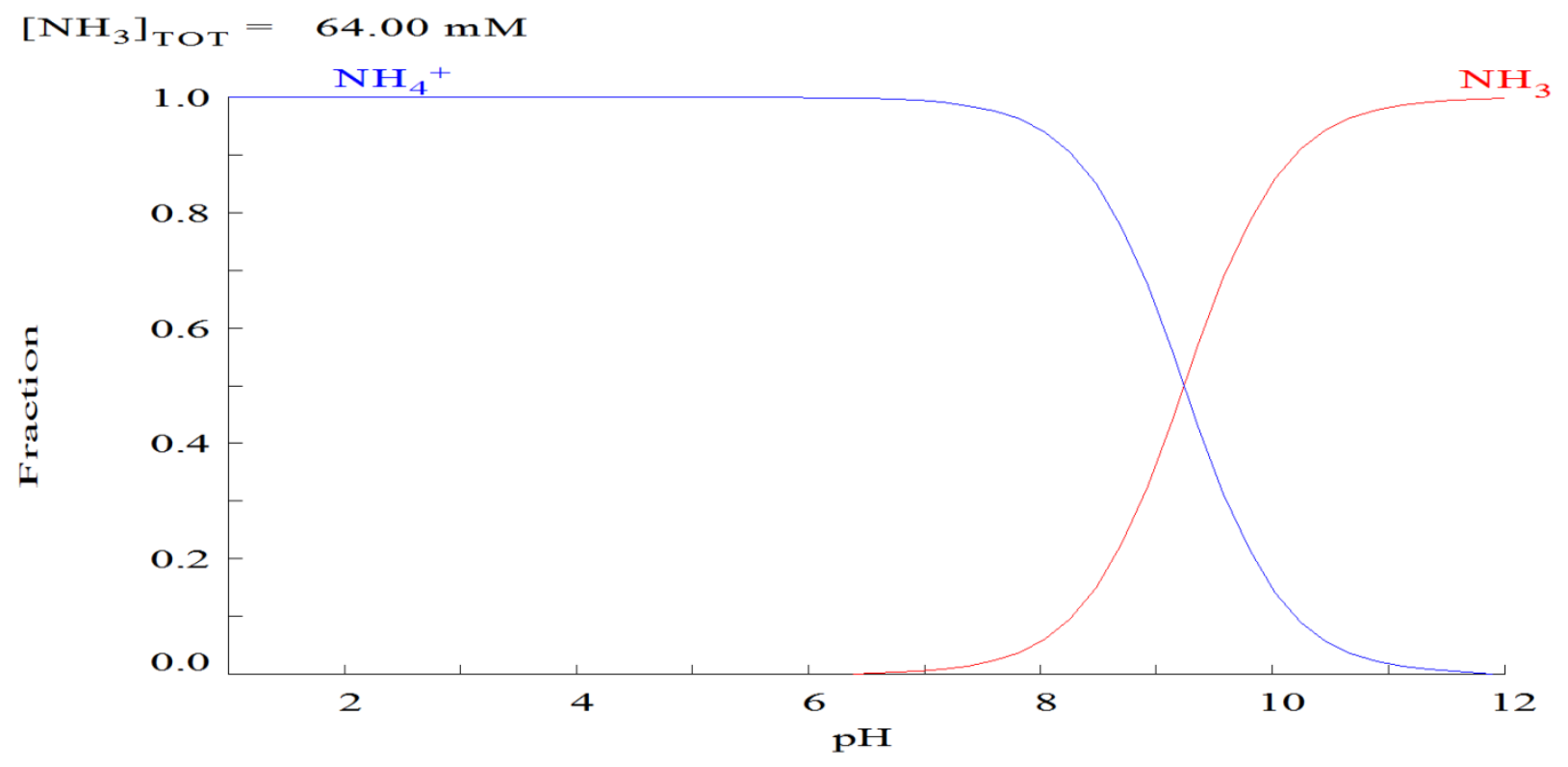

Figure 4. $\mathrm{NH}_{3}$ speciation versus $\mathrm{pH}$. Generated by use of Medusa-Hydra chemical equilibrium software.

The results after pretreatment at $\mathrm{pH}=12$ showed that ammonia was almost entirely removed from the solution. At high $\mathrm{pH}$ values essentially all nitrogen was in the form of ammonia, which could be removed by stripping (Figure 3). Also, as expected, during the course of pretreatment the $\mathrm{pH}$ was decreased as the ammonium-ammonia equilibrium was shifted to the left, consuming $\mathrm{OH}^{-}$. This was the reason for the final $\mathrm{pH}$ of 10.5 observed after the pretreatment.

\subsubsection{Carbonate system}

The equilibrium of gaseous and aqueous $\mathrm{CO}_{2}$ is:

$$
\mathrm{CO}_{2}(\mathrm{~g}) \leftrightarrow \mathrm{CO}_{2}(\mathrm{aq})
$$

where $\mathrm{CO}_{2}(\mathrm{aq})$ is the dissolved (aqueous) carbon dioxide. The concentration of $\mathrm{CO}_{2}$ as $\mathrm{CO}_{2}(\mathrm{aq})$ is not a function of $\mathrm{pH}$ because of the Henry's Law equilibrium between the large reservoir of 
gaseous $\mathrm{CO}_{2}$, i.e., the atmosphere, and the finite body of water. Following the dissolution of $\mathrm{CO}_{2}$, hydration and dissociation takes place and the resulting carbonate system equilibrium is:

$$
\mathrm{CO}_{2}(\mathrm{aq})+\mathrm{H}_{2} \mathrm{O} \leftrightarrow \mathrm{H}_{2} \mathrm{CO}_{3} \leftrightarrow \mathrm{HCO}_{3}{ }^{-}+\mathrm{H}^{+} \leftrightarrow \mathrm{CO}_{3}{ }^{2-}+2 \mathrm{H}^{+}
$$

where $\mathrm{H}_{2} \mathrm{CO}_{3}$ is typically in traces, as it is unstable. The $\mathrm{pH}$ of inorganic carbon-containing aqueous solution governs the speciation of the carbonate system and vice versa (Figure 5).

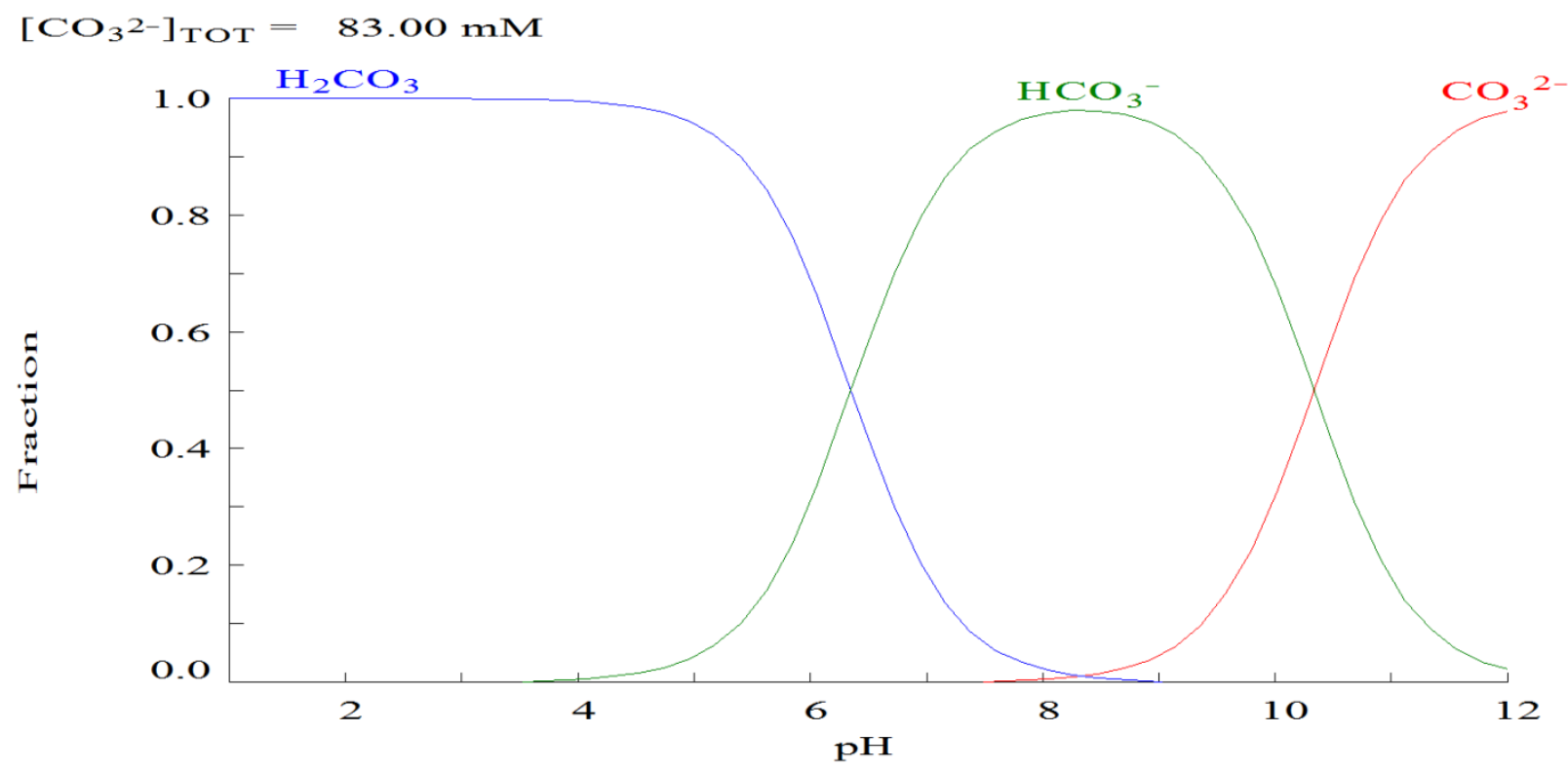

Figure 5. $\mathrm{CO}_{2}$ speciation versus $\mathrm{pH}\left[\mathrm{H}_{2} \mathrm{CO}_{3}=\mathrm{CO}_{2}(\mathrm{aq})+\mathrm{H}_{2} \mathrm{O}\right]$. Generated by use of MedusaHydra chemical equilibrium software.

The $\mathrm{pH}$ during stripping experiments without $\mathrm{pH}$ adjustment increased from 8.5 to 9.5. The increase of $\mathrm{pH}$ by removing $\mathrm{CO}_{2}$ is a well-known phenomenon [69]. This is due to the $\mathrm{CO}_{2}$ stripping driving the carbonate system to the formation of new $\mathrm{CO}_{2}(\mathrm{aq})$ with simultaneous consumption of $\mathrm{H}^{+}$. The final $\mathrm{pH}$ is determined by the $\mathrm{CO}_{2}$ of the air; the amount of $\mathrm{CO}_{2}$ stripped of the system is replaced by the air $\mathrm{CO}_{2}$ equilibrium is attained and no further change take place [69]. On the other hand, the results after pretreatment at $\mathrm{pH}=12$ showed that the amount of inorganic carbon present was substantially increased (Figure 3). This occured because at $\mathrm{pH}=12$ there were no appreciable amounts of $\mathrm{CO}_{2}(\mathrm{aq})$ to be stripped (Figure 5) and the aeration had the opposite effect, i.e. dissolution of $\mathrm{CO}_{2}(\mathrm{~g})$ from the air which was rapidly transformed into $\mathrm{CO}_{3}{ }^{2-}$. 
The total amount of $\mathrm{CO}_{2}$ (including all species, $\mathrm{HCO}_{3}{ }^{-}$and $\mathrm{CO}_{3}{ }^{2-}$,) that may dissolve in water is a function of $\mathrm{pH}$ and so the (total) solubility of $\mathrm{CO}_{2}$ at $25^{\circ} \mathrm{C}$ in water rises from $1.2 * 10^{-5} \mathrm{~mol} / \mathrm{L}$ at $\mathrm{pH}<5.5$ to $0.1 \mathrm{~mol} / \mathrm{L}$ at $\mathrm{pH}>10$. This explains why the total $\mathrm{CO}_{2}$ (aq) concentration is stable at pH below 5.5 since the major species is $\mathrm{CO}_{2}$ (aq) (Figure 5). Finally, under acidic conditions, $\mathrm{CO}_{3}{ }^{2-}$ and $\mathrm{HCO}_{3}{ }^{-}$combine with $\mathrm{H}^{+}$to produce unstable $\mathrm{H}_{2} \mathrm{CO}_{3}$ that is subsequently decomposed into $\mathrm{CO}_{2}(\mathrm{aq})$ and water resulting to bubbling when lowering the $\mathrm{pH}$ of leachate with addition of acid [60]. As it will be discussed in paragraph 3.4.1, this is what happens in the bioreactors experiments with manual $\mathrm{pH}$ control at 7; the continuous addition of $\mathrm{H}^{+}$promotes formation of new $\mathrm{CO}_{2}(\mathrm{aq})$ as equilibrium is shifted to the left. Hence, the $\mathrm{CO}_{2}$ (aq) removal by stripping continues until total inorganic carbon concentration reaches a concentration determined by solubility of $\mathrm{CO}_{2}(\mathrm{~g})$ and the carbonate system equilibrium reaction at this $\mathrm{pH}$ (Figure 5).

\subsection{Adsorption by use of activated carbon and natural zeolite}

The removal of TIC, TOC and ammonium-N achieved is shown in Figure 6 for the range of 0-18 $\mathrm{g} / \mathrm{L}$ of solids concentration (Experiments 3-7). Blank indicates the reference reactor (Experiment 1). The $\mathrm{pH}$ was increased from 8-8.5 to 9.2-9.5 in all experiments. As it is clear, with increasing concentrations of the adsorbents, higher ammonium and TOC removal was achieved, reaching 19.5\% TOC and 71\% $\mathrm{N}-\mathrm{NH}_{4}$ removal at $18 \mathrm{~g} / \mathrm{L}$. TIC removal fluctuated between $44-57 \%$ without showing any trend. This is in general agreement with the literature as it is known that AC can remove mainly organic compounds while natural zeolite mainly ammonia [57, 59]. 




Figure 6. $\mathrm{AC} / \mathrm{NZ}$ adsorption at different concentration. Equal amounts of activated carbon and natural zeolite were used, ranging in 3-18 g/L.

\subsection{Biological treatment}

\subsubsection{Single step biological treatment}

Figure 7 illustrates the biological treatment results under aerobic and anaerobic conditions (Experiments 8 and 11). Biological treatment under anaerobic conditions did not show any

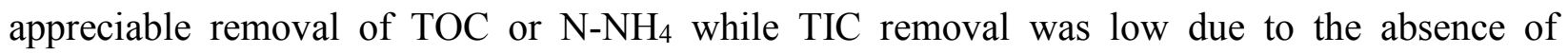
stripping. On the other hand, under aerobic conditions some removal of about $10.6 \%$ occurred for TOC, rising to $13.2 \%$ with initial adjustment of $\mathrm{pH}$ to 7 (Experiment 9). Also, the initial adjustment of $\mathrm{pH}$ at 7 increased the TIC removal from $51.8 \%$ to $70.7 \%$, and marginally the $\mathrm{N}$ $\mathrm{NH}_{4}$ removal from $47.9 \%$ to $51.1 \%$. The $\mathrm{pH}$ was increased from $8.2-8.5$ to $9.2-9.4$ in these 
experiments, a $\mathrm{pH}$ range which was slightly higher than about the value of 9 , which has been recommended for carbon removal by activated sludge [70].

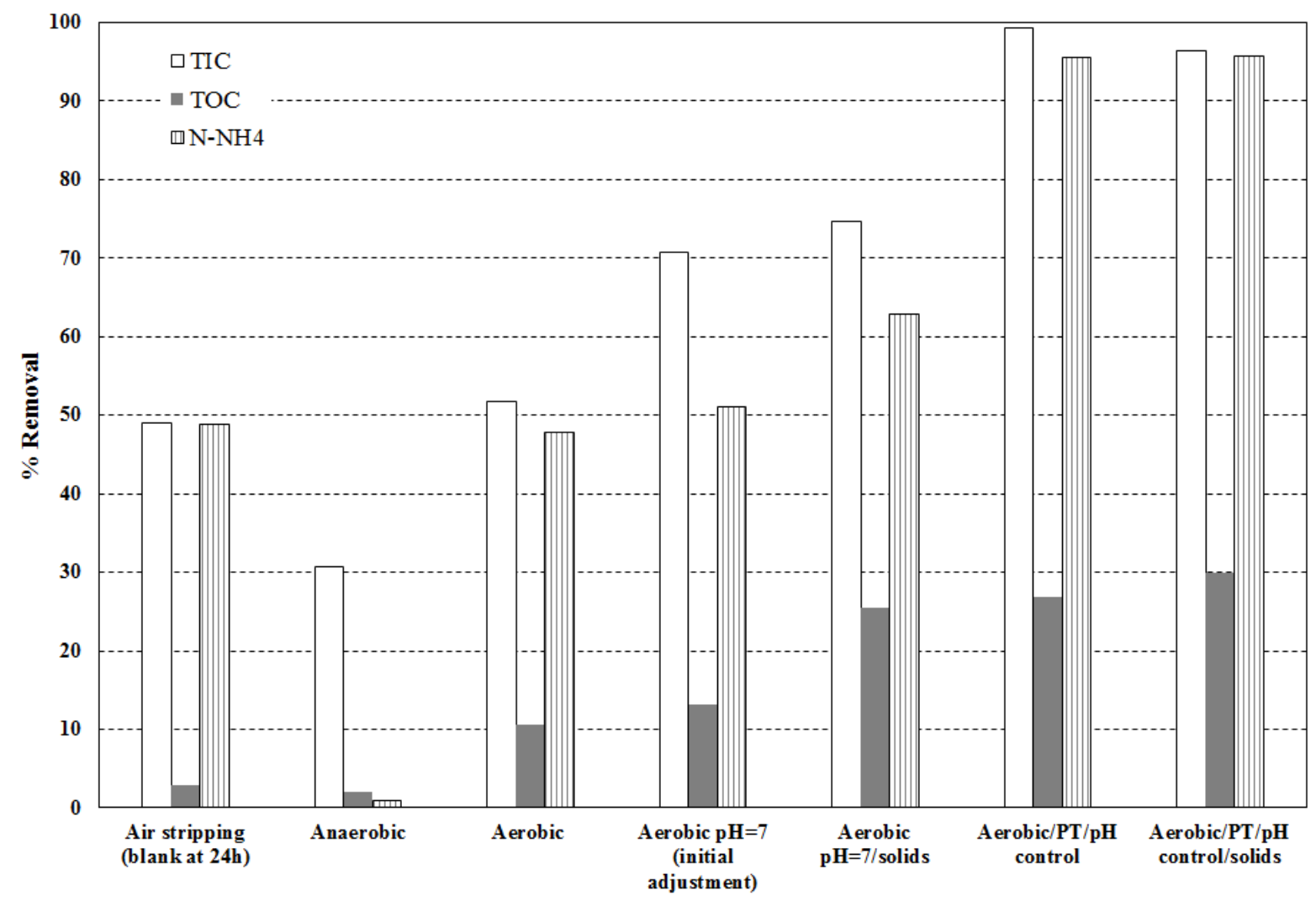

Figure 7. Aerobic and anaerobic biological treatment combinations.

Aerobic treatment with initial $\mathrm{pH}$ adjustment to 7 and $9 \mathrm{~g} / \mathrm{L}$ solids further improved the performance of the operation, as TOC removal reached $25.5 \%$, TIC $74.7 \%$ and $\mathrm{N}^{-\mathrm{NH}_{4}} 62.9 \%$ (Experiment 10). This clearly shows the positive effects of activated carbon (removal of organics) and zeolite (removal of ammonia). The TOC removal achieved when combining activated sludge and solids $(9 \mathrm{~g} / \mathrm{L})$ (Figure 7) was about equal to the sum of the adsorption with 9 $\mathrm{g} / \mathrm{L}$ solids, which was about 14\% (Figure 3) and biological oxidation with initial $\mathrm{pH}$ adjustment at 7 , which was about $13.2 \%$ (Figure 7 ).

To further investigate the dependence of biological activity on $\mathrm{N}-\mathrm{NH}_{4}$ and $\mathrm{pH}$, the combination of pretreatment at pH 12 and aerobic biological treatment is presented in Figure 7 (Experiment 12). In this set of experiments the $\mathrm{pH}$ was manually controlled for the first 2.5 hours at $\mathrm{pH}=7$, 
after which it remained in the range of 7-8 without further intervention. This assured optimum $\mathrm{pH}$ conditions for the activated sludge activity. Comparing the results under these conditions with the aerobic treatment (with or without initial $\mathrm{pH}$ adjustment to 7, Experiments 8 and 10), the improvement was considerable, as TOC removal reached $26.8 \%$, TIC 99.4\% and $\mathrm{N}_{-} \mathrm{NH}_{4} 95.6 \%$. TIC removal was due to the continuous control of $\mathrm{pH}$ (see paragraph 3.2.2) and $\mathrm{N}_{-} \mathrm{NH}_{4}$ removal due to the stripping at $\mathrm{pH}=12$ (see paragraph 3.2.1). This improvement in TOC removal can be attributed mainly to the removal of $\mathrm{N}_{-} \mathrm{NH}_{4}$, which in high concentrations is toxic and to lesser extend to the adequate $\mathrm{pH}$ range or the operation. However, the addition of solids to this combination only slightly improved the results obtained as TOC removal reached 29.9\% (Experiment 13). This shows that there was a limit to the TOC removal that could be achieved with the treatment methods used, which could be attributed to the presence of non-biodegradable and bio-refractory organic compounds. This was expected as the leachate was received from an old landfill and it was thus stabilized, containing possibly several xenobiotic organic compounds (XOCs) such as hormones, pharmaceuticals, personal care products (PCPs), pesticides, brominated flame retardants, industrial retardants, industrial products, household products, and disinfectants.

\subsubsection{Nitrification}

The difference in performance between aerobic and anaerobic treatment of leachate clearly favors the former. Despite the low organic carbon removal observed, some degree of nitrification was achieved under aerobic conditions. As mentioned above, the $\mathrm{pH}$ was increased from 8-8.5 to 9.2-9.4 in these experiments, a $\mathrm{pH}$ range which was higher than the value of 8.5 , which has been recommended for nitrification in activated sludge systems [71].

Figure 8 shows the accumulation of nitrates and nitrites, which indicates the presence of ammonia-oxidizing bacteria (AOB) and ammonia-oxidizing archaea (AOA) [64]. Oxidation of ammonium into nitrate through intermediate nitrite is known as nitrification. The reaction is as follows:

$$
\begin{gathered}
2 \mathrm{NH}_{4}^{+}+3 \mathrm{O}_{2} \leftrightarrow 2 \mathrm{NO}_{2}^{-}+2 \mathrm{H}_{2} \mathrm{O}+4 \mathrm{H}^{+} \\
2 \mathrm{NO}_{2}{ }^{-}+\mathrm{O}_{2} \leftrightarrow 2 \mathrm{NO}_{3}{ }^{-}
\end{gathered}
$$


Denitrification occurs under anoxic conditions, which results in reduction of nitrates to nitrogen. The aeration rate has a complex influence on nitrification and denitrification processes. The most essential parameters of these processes include the initial amount of nitrogen compounds in the reactor, aeration rate, activated sludge volume, as well as the quantity and characteristics of the existing organic substances [72]. As it is evident from Figure 8, some nitrification occured in the aerobic reactor and some denitrification in the anaerobic reactor, as expected. This shows that nitrification and denitrification processes were not entirely inhibited under the experimental conditions studied in this research, however the ammonia removal was almost entirely due to stripping or adsorption.

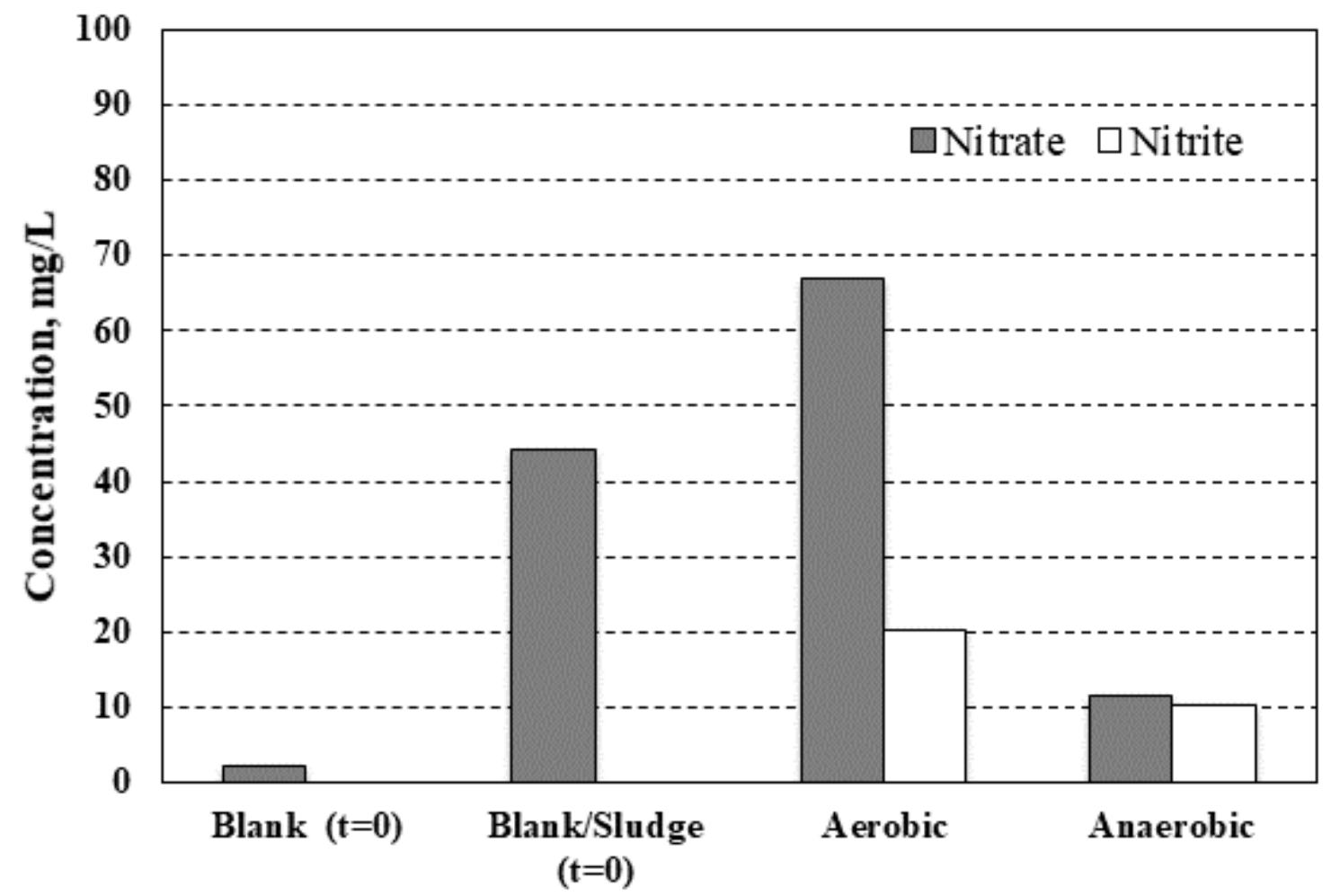

Figure 8. Nitrate and nitrite concentrations after nitrification.

\subsubsection{Sequential aerobic and anaerobic treatment}

Aerobic sludge treatment followed by anaerobic and vice versa can enhance the degradation of organic matter compared to single step treatment [64]. In this set of experiments, the pH was increased from 8-8.5 to 9.3-9.6, a $\mathrm{pH}$ range, which was slightly higher than 9, a $\mathrm{pH}$ value 
recommended for carbon removal by activated sludge (Experiments 14-16). Also, while after 12 $\mathrm{h}$ treatment in anaerobic/aerobic (An/Aero) combination, the $\mathrm{pH}$ reached 7.1-8.1 (due to absence of TIC stripping), that of aerobic/anaerobic (Aero/An) combination was around 9.5. However, that did not seem to have any effect on the performance of the reactors with combined aerobic/anaerobic steps (Figure 9).

The reactors with combined biological steps reached a TOC removal of $24.8-29.6 \%$ and with the addition of solids, $36.7 \%$. Again, the benefits of the $\mathrm{N}^{-\mathrm{NH}_{4}}$ removal by pretreatment at $\mathrm{pH}=12$ were evident but the combination of aerobic and anaerobic steps did not seem to offer much in comparison to single aerobic reactors unless combined to adsorption (Experiment 16), as it increased the TOC removal from $29.9 \%$ in the respective aerobic reactor to $36.7 \%$ (Figure 7 ). The almost $100 \%$ removal of $\mathrm{N}-\mathrm{NH}_{4}$ was due to the pretreatment at $\mathrm{pH} 12$ and the low TIC removal was due to the reduced aeration time (12 $\mathrm{h}$ in Aero mode).

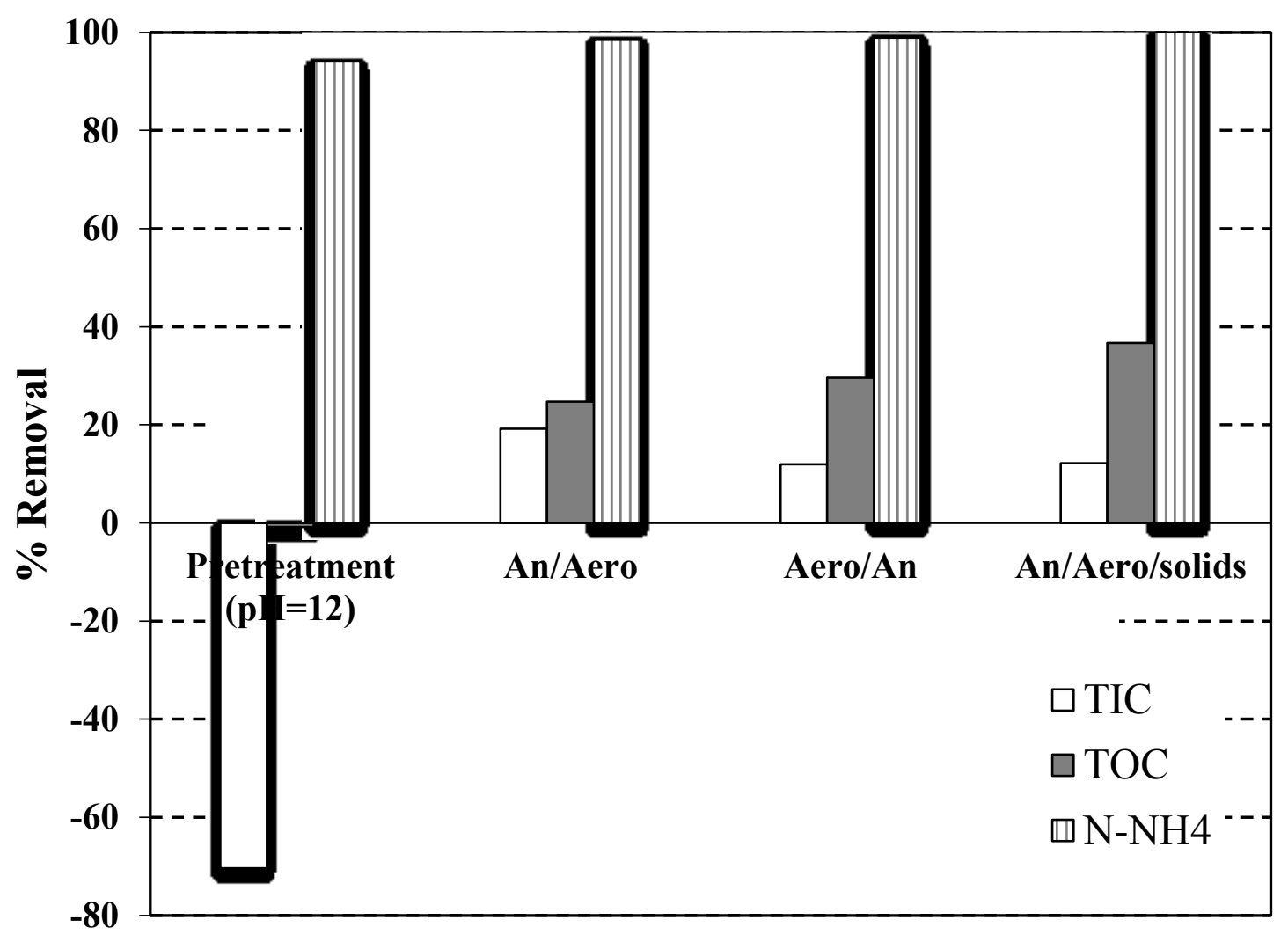

Figure 9. Sequential aerobic/anaerobic and anaerobic/aerobic treatment (with pretreatment). 


\subsubsection{Effect of $\mathrm{pH}$ control}

It is known that $\mathrm{pH}$ has a significant effect on the activity of activated sludge with the optimum value ranging in 7-8. In Figure 10, the evolution of $\mathrm{pH}$ with time after its initial adjustment at 7 in the aerobic and anaerobic reactor experiments is shown (Experiments 9 and 11). It can be observed that $\mathrm{pH}$ increased sharply at the first 3 hours of the experiment, which can be attributed to high $\mathrm{CO}_{2}$ mass transfer rates due to stripping at the beginning of the process.

In order to test the performance of biological treatment during the first hours, samples were withdrawn at the beginning $(\mathrm{t}=1 \mathrm{~h})$ and after completion of the experiment $(\mathrm{t}=24 \mathrm{~h})$. TOC removal efficiency was $28 \%$ and $30 \%$, respectively, which shows that the adsorption and biological processes took place mainly during the first hours of treatment (Figure 11). The difference in inorganic carbon and ammonium removal was due to longer air stripping in the second case.

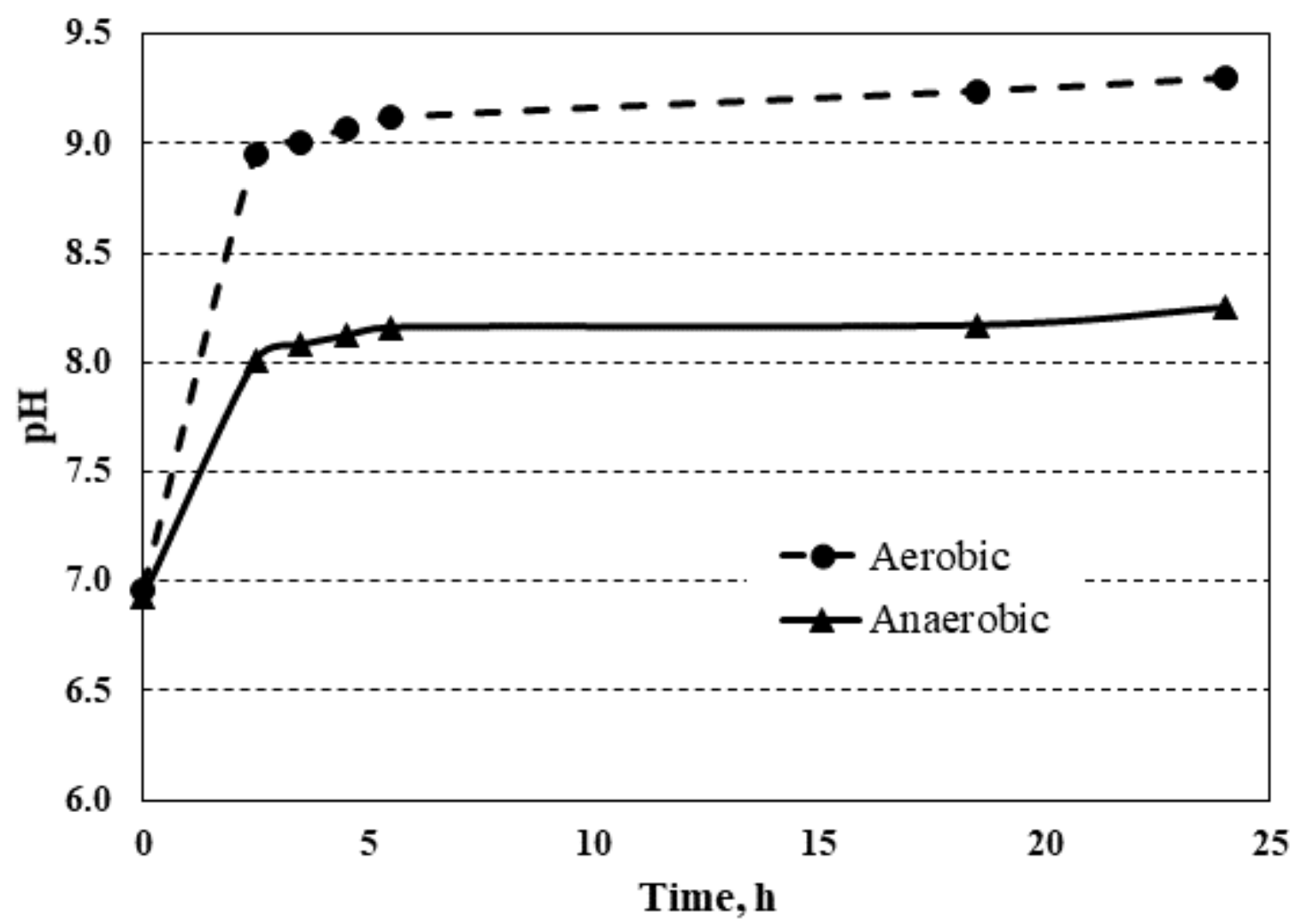

Figure 10. $\mathrm{pH}$ variation with time after initial adjustment at $\mathrm{pH}=7$. 


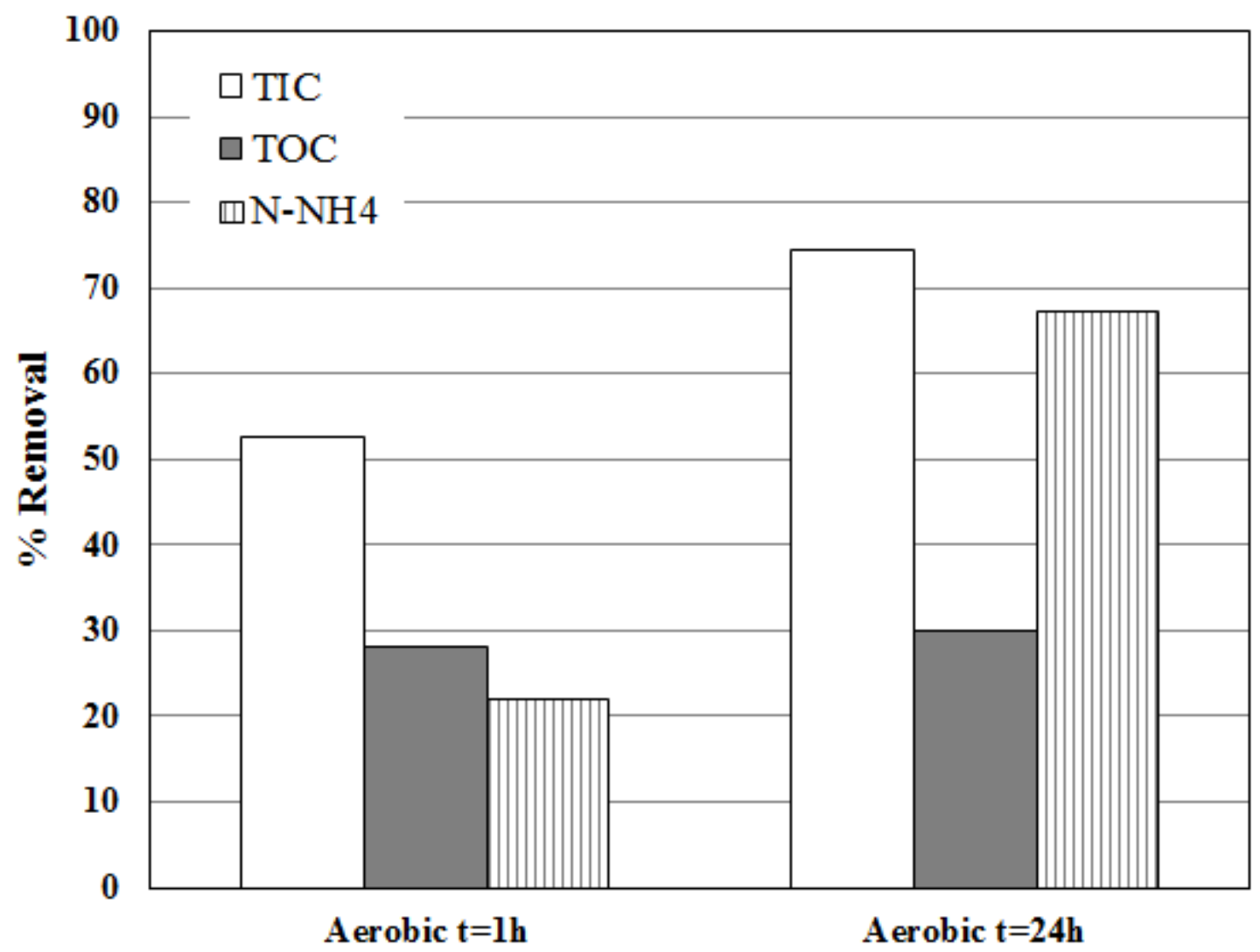

Figure 11. Aerobic bioreactors performance at solids concentration of $9 \mathrm{~g} / \mathrm{L}$ and initial $\mathrm{pH}$ adjustment at 7 .

\subsection{Photochemical treatment}

The leachate used in photochemical experiments had initial TC concentration around 2450-2700 $\mathrm{mg} / \mathrm{L}$ with 1100-1200 mg/L being inorganic carbon. So, inorganic carbon accounted for around $45 \%$ of total carbon in the leachate. Total nitrogen was $900-1100 \mathrm{mg} / \mathrm{L}$ and initial $\mathrm{pH} 8.3$. Initially, $13320 \mathrm{mg} / \mathrm{L} \mathrm{H}_{2} \mathrm{O}_{2}$ were used to treat the solution. As shown in Figure 12, the TC removal obtained after $2 \mathrm{~h}$ remained below $5 \%$. Then, the leachate was further diluted with water to an initial TC equal to $540 \mathrm{mg} / \mathrm{L}$ and $2664 \mathrm{mg} / \mathrm{L} \mathrm{H}_{2} \mathrm{O}_{2}$ were used. The TC removal obtained was $11.8 \%$, still too low to be of any practical use. The addition of $80 \mathrm{ppm}$ (w/w) Fe(III) only led to a TC removal $22.3 \%$. The amounts of $\mathrm{H}_{2} \mathrm{O}_{2}$ and $\mathrm{Fe}$ (III) used were the optimum ones found in earlier experiments for achieving $80 \%$ mineralization of a synthetic municipal wastewater with 
similar initial TC $(\approx 540 \mathrm{mg} / \mathrm{L})$. Since decreasing the initial TC by a factor about 5 and adding $\mathrm{Fe}(\mathrm{III})$ did not lead to any remarkable results, the next step included the adjustment of initial $\mathrm{pH}$ to the acidic range. So, decreasing the initial $\mathrm{pH}$ to 4.99 by means of hydrochloric acid, while keeping the same initial concentrations of all components $\left(\mathrm{TC}=540 \mathrm{mg} / \mathrm{L}, \mathrm{H}_{2} \mathrm{O}_{2}=2664 \mathrm{mg} / \mathrm{L}\right.$, $\mathrm{Fe}(\mathrm{III})=80 \mathrm{ppm})$, increased markedly the TC removal achieved after $2 \mathrm{~h}$ to $69.8 \%$. The TC removal observed was mainly due to the removal of most inorganic carbon from the solution almost instantly as a result of the initial $\mathrm{pH}$ adjustment.

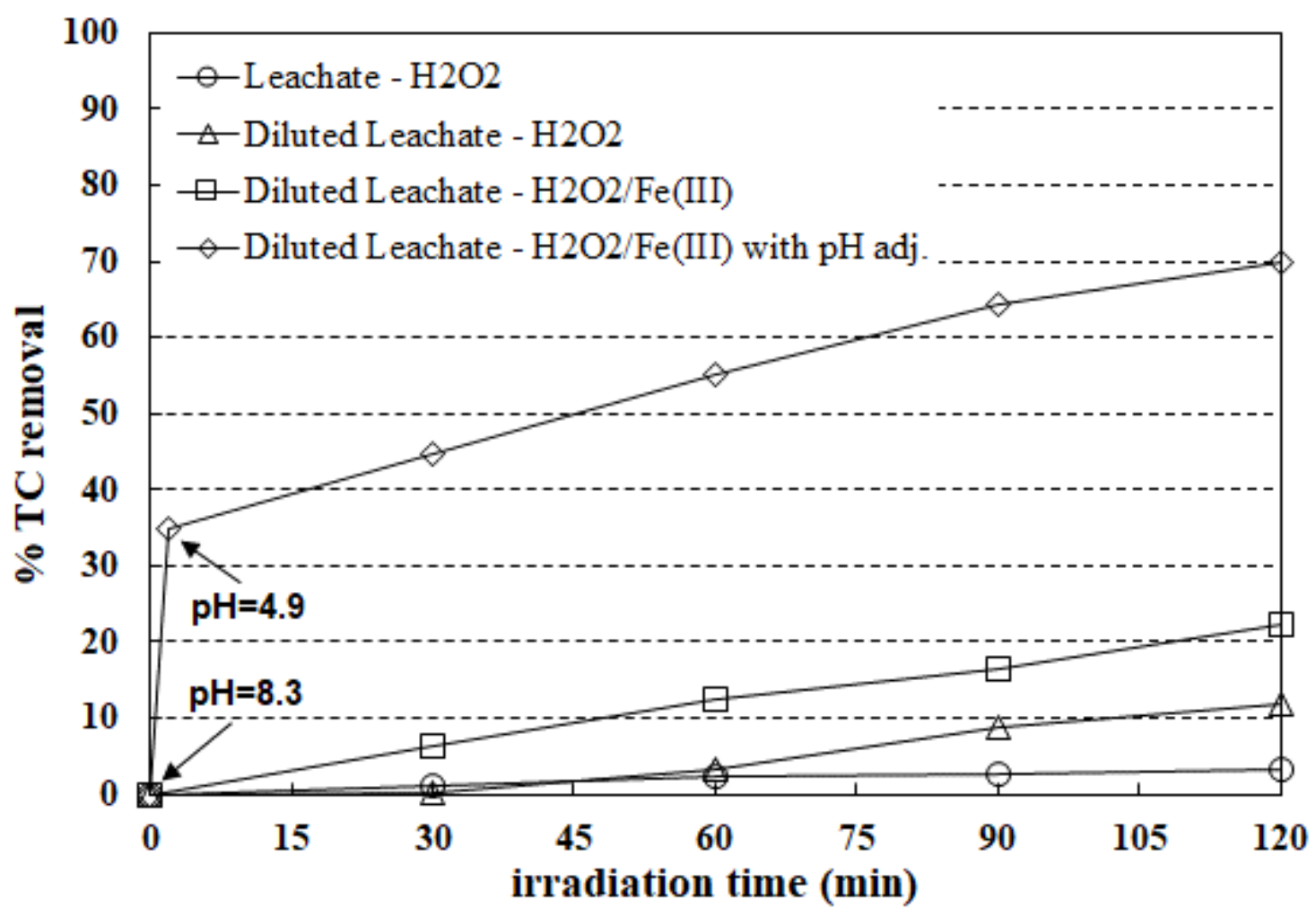

Figure 12. TC removal in the photochemical treatment of leachate.

The next step was to apply the combination of hydrogen peroxide, ferric ions and initial $\mathrm{pH}$ adjustment to a value below 5 for the initial leachate (undiluted, not treated) as well as for the treated leachate $(\mathrm{TC}=930 \mathrm{mg} / \mathrm{L}, \mathrm{pH}=7.8)$. The treatment time was extended to $150 \mathrm{~min}$. The results obtained are depicted in Figure 13. The TC removals obtained for the (undiluted, not treated) leachate were similar to the ones for the diluted one with $\mathrm{pH}$ adjustment shown in Figure 12. When the treated leachate was used as feed in the photochemical process, the increase in the 
initial concentration of hydrogen peroxide led to increased TC removals obtained, which were lower than the ones for the (undiluted, not treated) leachate, since most inorganic carbon had been already removed in the bio-treatment (Figure 14). Foaming was observed during these experiments.

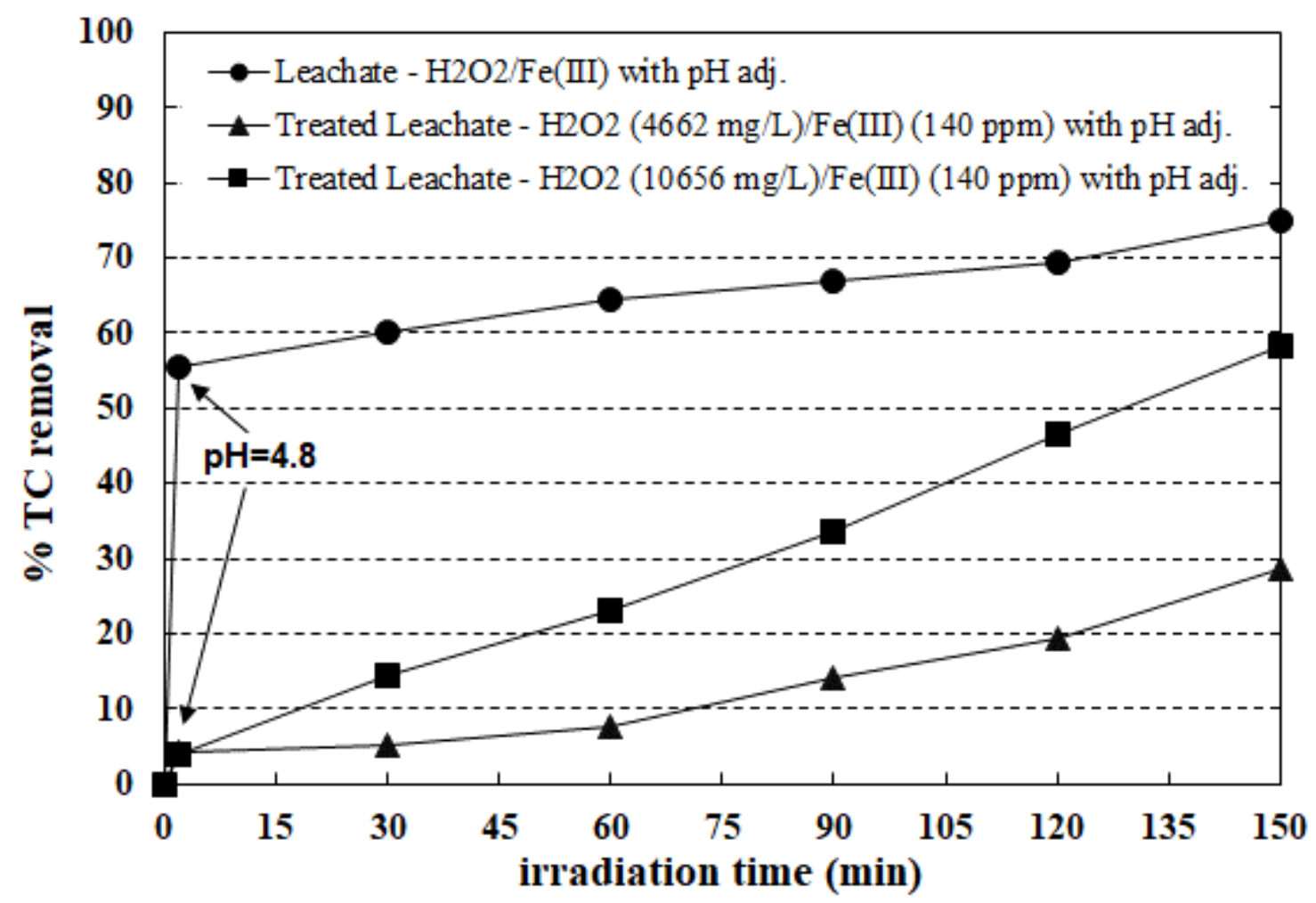

Figure 13. TC removal in the photochemical treatment of leachate and treated leachate with initial $\mathrm{pH}$ adjustment.

It is thus interesting to determine the total organic carbon removal (TOC) in the process by removing the contribution of TIC to TC. As it is shown in Figure 15, TOC removal with $\mathrm{pH}$ adjustment in (undiluted, not treated) leachate reached $43 \%$. Also, with $\mathrm{pH}$ adjustment and increased initial amount of $\mathrm{H}_{2} \mathrm{O}_{2}, 58.7 \%$ TOC removal was achieved after $2.5 \mathrm{~h}$ for the treated leachate during the photochemical treatment. Regarding TN, the photochemical process had no impact on it. 


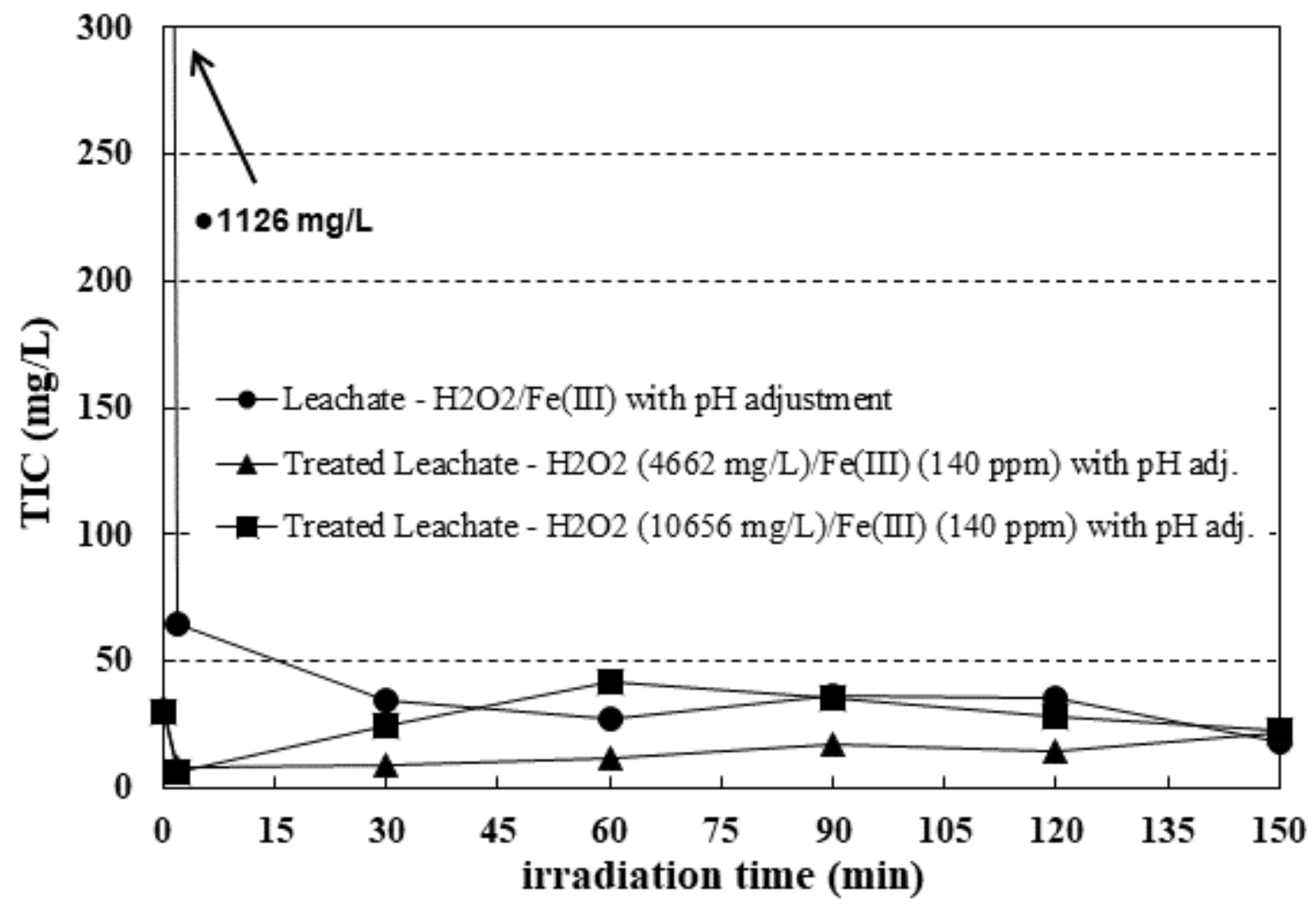

Figure 14. TIC removal in the photochemical treatment of leachate and treated leachate with initial $\mathrm{pH}$ adjustment. 


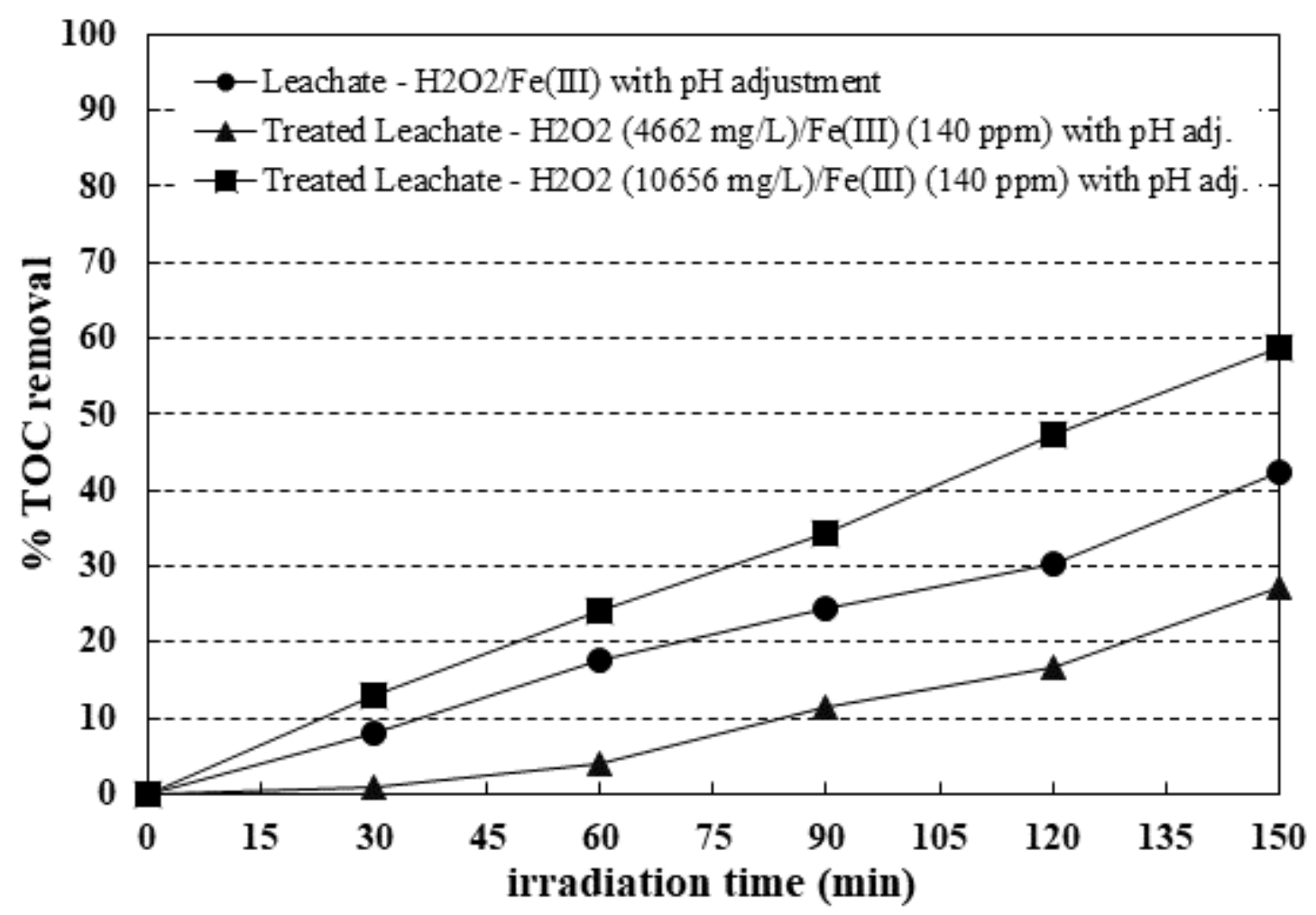

Figure 15. TOC removal in the photochemical treatment of leachate and treated leachate with initial $\mathrm{pH}$ adjustment.

Several efforts have been made to treat landfill leachates by means of photochemical [73] or combined biological-photochemical processes $[74,75]$. The results obtained in the present study are in accordance with the ones reported in similar ones. Specifically, when AOPs are used to treat landfill leachates, the TN removals obtained are low as a result of slow rates for ammonia nitrogen oxidation by hydroxyl radicals [76]. For ammonia nitrogen removal from leachates, stripping at high $\mathrm{pH}$ has been suggested among other options [60]. Foaming is also a common issue when AOPs are used in the treatment of leachates. Its formation can be attributed to either $\mathrm{CO}_{2}$ produced from carbonate species at low $\mathrm{pH}$ values or organic foaming agents in the leachate [77]. The low efficiency of the photochemical process before $\mathrm{pH}$ adjustment is related to the inorganic carbon initially present. Specifically, carbonate $\left(\mathrm{CO}_{3}{ }^{2-}\right)$ and bicarbonate $\left(\mathrm{HCO}_{3}{ }^{-}\right)$act as hydroxyl scavengers inhibiting thus the oxidation of organic molecules by hydroxyl radicals. The easiest way to remove these inorganic species so that the process can be effective in removing the organic carbon in the leachate is to decrease the $\mathrm{pH}$ with addition of acid [60]. As 
discussed earlier, under such conditions, $\mathrm{CO}_{3}{ }^{2-}$ and $\mathrm{HCO}_{3}{ }^{-}$combine with $\mathrm{H}^{+}$to produce unstable $\mathrm{H}_{2} \mathrm{CO}_{3}$ that is subsequently decomposed into $\mathrm{CO}_{2}(\mathrm{aq})$ and water. Organic compounds like humic substances are generally responsible for the initial dark color of leachates. The molecular weights of humic substances generally increase with landfill age [78]. As these large organic compounds are degraded into smaller and simpler molecules when an AOP is applied, decolorization efficiencies are commonly higher than COD removals. Reported values of COD and TOC removals range significantly depending on the leachate characteristics and process operating conditions $[4,60,79]$.

\section{Conclusions}

The complexity of leachate composition makes its treatment a challenging task. In the current study, physical (stripping, adsorption), biological (activated sludge process) and photochemical processes in single and combined steps were tested for an efficient treatment of this wastewater. Air stripping in two steps, i.e. at $\mathrm{pH}=12$ for the removal of ammonia and $\mathrm{pH}=7$ for the removal of carbonates was a necessary pretreatment process. The results showed that inorganic carbon and ammonia was almost entirely removed by air stripping at $\mathrm{pH}=7$ and $\mathrm{pH}=12$, respectively. This step is particularly important if aerobic biological process is employed; elevated ammonia is toxic for activated sludge while elevated carbonates content in combination to aeration leads to a $\mathrm{pH}$ increase beyond 9-9.5, which again inhibits the activated sludge activity. Adsorption, while not as crucial as stripping, is useful as it can remove part of the toxic organics that are difficult to be biologically or even chemically decomposed. The removal of organic carbon by stripping alone was lower than $4 \%$, but combined to adsorption reached $20 \%$, and to biological treatment $30 \%$. The combination of stripping, adsorption and biological treatment resulted in $37 \%$ organic carbon removal. Concerning the photochemical treatment, $\mathrm{pH}$ adjustment to $\mathrm{pH}=5$ is essential as for more basic solutions the process fails. A side effect of the $\mathrm{pH}$ adjustment is the removal of inorganic carbon. The removal of organic carbon by photochemical oxidation was $43 \%$ while the photochemical step had no effect on ammonia. Finally, the combination of air stripping, adsorption, biological and photochemical oxidation steps increased the organic carbon removal to $59 \%$. 


\section{References}

[1] A.M. Schiopu, M. Gavrilescu, Options for the Treatment and Management of Municipal Landfill Leachate: Common and Specific Issues, Clean - Soil, Air, Water., 38 (2010) 11011110.

[2] V.J. Inglezakis, K. Moustakas, G. Khamitov, D. Tokmurzin, R. Rakhmatulina, B. Serik, Y. Abikak, S.G. Poulopoulos, Municipal Solid Waste Management in Kazakhstan: Astana and Almaty Case Studies, Chem. Eng. Trans., 56 (2017) 565-570

[3] International Finance Corporation, WorldBank Group, Municipal Solid Waste Management: Opportunities for Russia-Summary of key findings, 2012.

[4] S. Renou, J.G. Givaudan, S. Poulain, F. Dirassouyan, P. Moulin, Landfill leachate treatment: Review and opportunity, J. Hazard. Mater., 150 (2008) 468-493.

[5] V.J. Inglezakis, L. Rojas-Solórzano, J. Kim, A. Aitbekova, A. Ismailova, Comparison between landfill gas and waste incineration for power generation in Astana, Kazakhstan, Waste Manag. Res., 33 (2015) 486-494.

[6] R.B. Brennan, M.G. Healy, L. Morrison, S. Hynes, D. Norton, E. Clifford, Management of landfill leachate: The legacy of European Union Directives, Waste Manag., 55 (2016) 355363.

[7] P. Kjeldsen, M.A. Barlaz, A.P. Rooker, A. Baun, A. Ledin, T.H. Christensen, Present and Long-Term Composition of MSW Landfill Leachate: A Review, Crit. Rev. Environ. Sci. Technol., 32 (2002) 297-336.

[8] Y. Ren, F. Ferraz, M. Lashkarizadeh, Q. Yuan, Comparing young landfill leachate treatment efficiency and process stability using aerobic granular sludge and suspended growth activated sludge, J. Water Process Eng., 17 (2017) 161-167.

[9] S.M. Dario Bove, D. Frumento, S.A. Arni, B. Aliakbarian, A. Converti, A Critical Review of Biological Processes and Technologies for Landfill Leachate Treatment, Chem. Eng. Technol., 38 (2015) 2115-2126.

[10] H. Alvarez-Vazquez, B. Jefferson, S.J. Judd, Membrane bioreactors vs conventional biological treatment of landfill leachate: A brief review, J. Chem. Technol. Biotechnol., 79 (2004) 1043-1049. 
[11] T. Robinson, Removal of toxic metals during biological treatment of landfill leachates, Waste Manag., 63 (2017) 299-309.

[12] B.P. Naveen, D.M. Mahapatra, T.G. Sitharam, P.V. Sivapullaiah, T.V. Ramachandra, Physico-chemical and biological characterization of urban municipal landfill leachate, Environ. Pollut., 220 (2016) 1-12.

[13] D.R. Ramires-Sosa, E.R. Castillo-Borges, R.I. Mendez-Novelo, M.R. Sauri-Riancho, M. Barcel-Quintal, J.M. Marrufo-Gomez, Determination of organic compounds in landfill leachates treated by Fenton-Adsorption, Waste Manag, 33 (2013) 390-395.

[14] S. Speer, P. Champagne, B. Anderson, Pilot-scale comparison of two hybrid-passive landfill leachate treatment systems operated in a cold climate, Bioresour. Technol., 104 (2012) 119126.

[15] C. Yaman, H.K. Ozcan, G. Demir, H.E. Okten, S. Yildiz, A. Coban, V. Balahorli, Landfill Leachate Treatment: A Case Study for Istanbul City, Clean-Soil Air Water., 40 (2012) 706711.

[16] H. Modin, K.M. Persson, A. Andersson, M.v. Praagh, Removal of metals from landfill leachate by sorption to activated carbon, bone meal and iron fines, J. Hazard. Mater., 189 (2011) 749-754.

[17] I. Trabelsi, H. Horibe, N. Tanaka, T. Matsuto, Origin of low carbon/nitrogen ratios in leachate from old municipal solid waste landfills, Waste Manag., 18 (2000) 224-234.

[18] S. Xie, Y. Ma, P.J. Strong, W.P. Clarke, Fluctuation of dissolved heavy metal concentrations in the leachate from anaerobic digestion of municipal solid waste in commercial scale landfill bioreactors: The effect of $\mathrm{pH}$ and associated mechanisms, J. Hazard. Mater., 299 (2015) 577-583.

[19] M. Barlaz, C. Bareither, A. Hossain, J. Saquing, I. Mezzari, C. Benson, T. Tolaymat, R. Yazdani, Performance of North American bioreactor landfills. II: chemical and biological characteristics, J. Environ. Eng., 136 (2010) 839-853.

[20] D.L. Baun, T.H. Christensen, Speciation of Heavy Metals in Landfill Leachate: A Review, Waste Manag. Res., 22 (2004) 3-23.

[21] S.C. Gutirrez-Gutirrez, F. Coulon, Y. Jiang, S. Wagland, Rare earth elements and critical metal content of extracted landfilled material and potential recovery opportunities, Waste Manag., 42 (2015) 128-136. 
[22] B.A.-Y.D. Reinhart, The impact of leachate recirculation on municipal solid waste landfill operating characteristics, Waste Manag. Res., 14 (1996) 337-346.

[23] Y. Wang, Landfill management in the aftercare period of municipal waste landfills, (2013).

[24] J.M. Lema, R. Mendez, R. Blazquez, Characteristics of landfill leachates and alternatives for their treatment: a review, Water, Air, Soil Pollut., 40 (1988) 223-250.

[25] J. Rodríguez, L. Castrillón, E. Marañón, H. Sastre, E. Fernández, Removal of nonbiodegradable organic matter from landfill leachates by adsorption, Water Res., 38 (2004) 3297-3303.

[26] M.C.S. Amaral, C.F.A. Ferreira, L.C. Lange, S.F. Aquino, Characterization of landfill leachates by molecular size distribution, biodegradability, and inert chemical oxygen demand, Water Environ. Res., 81 (2009) 499-505.

[27] H. Mishra, M. Rathod, S. Karmakar, R. Kumar, A framework for assessment and characterization of municipal solid waste landfill leachate: an application to the Turbhe landfill, Navi Mumbai, India, Environ. Monit. Assess., 188 (2016) 357.

[28] F.A. El-Gohary, G. Kamel, Characterization and biological treatment of pre-treated landfill leachate, Ecol. Eng., 94 (2016) 268-274.

[29] J. Dominguez, C. Costa, B. Autran, M.C. Marquez, Characterization and biological stabilization of leachates from solid wastes in north-centre Spain for agricultural application, Waste Biomass Valor (2017).

[30] L.A. Alver, Characterization and eletrocoagulative treatment of landfill leachates: a statistical approach, Process Saf. Environ. Prot., 3 (2017) 102-111.

[31] G. Andreottola, P. Cannas, Chemical and biological characteristics of landfill leachate, Elsevier Appl. Sci., 65 (1992).

[32] L.M. Chu, K.C. Cheung, M.H. Wong, Variations in the chemical-properties of landfill leachate, Environ. Manag., 18 (1994) 105.

[33] H.D. Robinson, The technical aspects of controlled waste management. A review of the composition of leachates from domestic wastes in landfill sites. Report for the UK Department of the Environment, Waste Sci. Res., (1995).

[34] H.J. Ehrig, Beitrag zum quantitativen und quantitativen Wasserhaushalt von Millldeponien, (1980). 
[35] H.J. Ehrig, Quality and quantity of sanitary landfill leachate, Waste Manag. Res., 1 (1983) 53-68.

[36] H.J. Ehrig, Water and element balances of Landfills, Springer Verlag, 20 (1988) 83-116.

[37] G.A. Garland, D.C. Mosher, Leachate effects of improper land disposal, Waste Age 6 (1975) 42.

[38] O.J. Johansen, D.A. Carlson, Characterization of sanitary landfill leachates, Water Res., 10 (1976) 1129-1134.

[39] K.H. Karstensen, Priority pollutants in leachate from landfills, Statens Forurensningstilsyn (1989).

[40] M.N. Krug, R.K. Ham, Analysis of long-term leachate characteristics, 51 (1991).

[41] J.C.S. Lu, B. Eichenberger, R.J. Steams, Leachate from municipal landfills-production and management, Noyes Publications, 1985.

[42] Naturvardsverket, Biological and chemical characterization of leachates (in Swedish), (1989).

[43] J.A. Owen, D.A.C. Manning, Silica in landfill leachates: Implications for clay mineral stabilities, Appl. Geochem., 12 (1997) 267.

[44] H.D. Robinson, P.J. Mafis, Leachate from domestic waste: generation, composition, and treatment (WRC Technical Report TR 108), Water Research Centre (1979).

[45] P. Kjeldsen, M. Christophersen, Composition of leachate from old landfills in Denmark, Waste Manag. Res., 19 (2001) 249-256.

[46] M.N. Krug, R.K. Ham, Analysis of long-term leachate characteristics, (1997) 117-131.

[47] O.T. Clement, Application of ultra-violet spectrophotometry and gel permeation chromatography to the characterization of landfill leachates, Environ. Technol., 16 (1995) 367-377.

[48] M. Jorgensen, P. Kjeldsen, Composition of leachate from old landfills, (1995) 16.

[49] P.H. Chen, Assessment of leachates from sanitary landfills: impact of age, rainfall and treatment, Environ. Inter., 22 (1996) 225-237.

[50] J. Gao, V. Oloibiri, M. Chys, W. Audenaert, B. Decostere, Y. He, H.V. Langenhove, K. Demeestere, S.W.V. Hulle, The present status of landfill leachate treatment and its development trend from a technological point of view, Rev. Environ. Sci. Bio/Technol., 14 (2015) 93-122. 
[51] J. Wiszniowski, D. Robert, J. Surmacz-Gorska, K. Miksch, J.V. Weber, Landfill Leachate Treatment Methods: A Review, Environ. Chem. Lett., 4 (2006) 51-61.

[52] J. Bohdziewicz, M. Bodzek, J. Gorska, Application of pressure-driven membrane techniques to biological treatment of landfill leachate, Process Biochem., 36 (2001) 641646.

[53] D. Trebouet, J.P. Schlumpf, P. Jaounen, F. Quemeneur, Stabilized landfill leachate treatment by combined physicochemi-cal-nanofiltration processes, Water Res., 35 (2001) 2935-2942.

[54] D.H. Ahn, C. Yun-Chul, C. Won-Seok, Use of coagulant and zeolite to enhance the biological treatment efficiency of high ammonia leachate, J. Environ. Sci. Heal. A: Toxic/Hazardous Substances Environ. Eng., 37 (2002) 163-173.

[55] S.K. Marttinen, R.H. Kettunen, K.M. Sormunen, R.M. Soimasuo, J.A. Rintala, Screening of physical-chemical methods for removal of organic material, nitrogen and toxicity from low strength landfill leachates, Chemosphere 46 (2002) 851-858.

[56] R. Mendez, J.M. Lema, R. Blazquez, M. Pan, C. Forjan, Characterization, digestibility and anaerobic treatment of leachates from old and young landfills, Water Sci. Technol., 21 (1989) 145-155.

[57] F. Kargi, M. Pamukoglu, Simultaneous adsorption and biological treatment of pre-treated landfill leachate by fed-batch operation, Process Biochem., 38 (2003) 1413-1420.

[58] U. Welander, T. Henrysson, Physical and chemical treatment of a nitrified leachate from a municipal landfill, Environ. Technol., 19 (1998) 591-599.

[59] N. Aghamohammadi, H. Mohamed, H. Isa, A. Zinatizadeh, Powdered activated carbon augmented activated sludge process for treatment of semi-aerobic landfill leachate using response surface methodology, Bioresour. Technol., 98 (2007) 3570-3578.

[60] Y. Deng, Advanced oxidation processes (AOPs) for reduction of organic pollutants in landfill leachate: a review, Int. J. Environ. Waste Manag., 4 (2009) 366-384.

[61] S.-M. Kim, S.-U. Geissen, A. Vogelpohl, Landfillleachate treatment by a photoassisted Fenton reaction, Wat. Sci. Tech., 35 (1997) 239-248.

[62] I.M.-C. Lo, Characteristics and treatment of leachates from domestic landfills, Environ. Inter., 22 (1997) 433-442. 
[63] K.J. Kennedy, E.M. Lentz, Treatment of landfill leachate using sequencing batch and continuous flow upflow anaerobic sludge blanket (UASB) reactors, Water Res., 34 (2000) $3640-3656$.

[64] R.H. Kettunen, T.H. Hoilijoki, J.A. Rintala, Anaerobic and sequential anaerobic-aerobic treatments of municipal landfill leachate at low temperatures, Bioresour. Technol., 58 (1996) $31-40$.

[65] F. Cecen, O. Aktas, Effect of PAC addition in combined treatment of landfill leachate and domestic wastewater in semi-continuously fed-batch and continuous-flow reactors, Water SA, 27 (2001) 177-188.

[66] S. Park, K.S. Choi, K.S. Joe, W.H. Kim, H.S. Kim, Variations of landfill leachate's properties in conjunction with the treatment process, Environ. Technol., 22 (2001) 639-645.

[67] M. Steensen, Chemical oxidation for the treatment of leachate - process comparison and results from full-scale plants, Water Sci. Technol., 35 (1997) 249-256.

[68] Standard methods for Determination of Water and Wastewater. 22nd ed, American Public Health Association, USA: Washington DC, 2012.

[69] Y. Cohen, H. Kirchmann, Increasing the $\mathrm{pH}$ of wastewater to high levels with different gases-CO2 stripping, Water, Air, Soil Pollut., 159 (2004) 265-275.

[70] E. Keefer, J. Meisel, Activated Sludge Studies: III. Effect of pH of Sewage on the Activated Sludge Process, Sewage Ind. Wastes, 23 (1951) 982-991.

[71] A.R. Dincer, F. Kargi, Effects of operating parameters on performances of nitrification and denitrification processes, Bioprocess Eng., 23 (2000) 75-80.

[72] M.A. Kamaruddin, M.S. Yusoff, H.A. Aziz, Y.-T. Hung, Sustainable treatment of landfill leachate, Appl. Water Sci., 5 (2015) 113-126.

[73] D.E. Daniel, E. Meeroff, F. Bloetscher, D.V. Reddy, F. Gasnier, S. Jain, A. McBarnette, H. Hamaguchi, Application of photochemical technologies for treatment of landfill leachate, J. Hazard. Mater., 209-210 (2012) 299-307.

[74] I.-O. Koh, X. Chen-Hamacher, K. Hicke, W. Thiemann, Leachate treatment by the combination of photochemical oxidation with biological process, J. Photochem. Photobiol., A162 (2004) 261-271. 
[75] M. Hassan, X. Wang, F. Wang, D. Wu, A. Hussain, B. Xie, Coupling ARB-based biological and photochemical (UV/TiO2 and UV/S2O82-) techniques to deal with sanitary landfill leachate, Waste Manage., 63 (2017) 292-298.

[76] J. Englehardt, Y. Deng, D. Meeroff, Y. Legrenzi, J. Mognol, J. Polar, Options for managing municipal landfill leachate: Year 1 development of iron-mediated treatment processes, Technical Report, (2006).

[77] Y. Deng, J.D. Englehardt, Treatment of landfill leachate by the Fenton process, Water Res., 40 (2006) 3683-3694.

[78] K.-H. Kang, H.S. Shin, H. Park, Characterization of humic substances present in landfill leachates with different landfill ages and its implications, Water Res., 36 (2002) 4023-4032.

[79] S.P. Cho, S.C. Hong, S.-I. Hong, Study of the end point of photocatalytic degradation of landfill leachate containing refractory matter, Chem. Eng. J., 98 (2004) 245-253. 